\title{
Assessing and comparing antioxidant activities of lactobacilli strains by using different chemical and cellular antioxidant methods
}

\author{
Guangqing Mu, ${ }^{\dagger}$ Yuan Gao, ${ }^{+} \dagger$ Yanfeng Tuo, ${ }^{\dagger}{ }^{1}$ Huanyu Li, ${ }^{*}$ Yuqing Zhang, ${ }^{*}$ Fang Qian, ${ }^{*} \dagger$ \\ and Shujuan Jiang*† \\ *School of Food Science and Technology, and \\ †Dalian Probiotics Function Research Key Laboratory, Dalian Polytechnic University, Dalian 116034, P. R. China
}

\begin{abstract}
Some lactobacilli strains had beneficial effects on human beings due to their antioxidant activities. In this study lactobacilli strains stored in our laboratory were screened for potential antioxidant activities by investigating their 1,1-diphenyl-2-picrylhydrazyl free radical scavenging activity, oxygen radical absorbance capacity, resistance to $\mathrm{H}_{2} \mathrm{O}_{2}$, and hydroxyl free radical scavenging activity; then the antioxidant activities of the screened strains were evaluated by cellular antioxidant assay and protection for HT-29 cells against $\mathrm{H}_{2} \mathrm{O}_{2}$ injury assay. The results showed that Lactobacillus plantarum Y44 could scavenge oxygen free radicals, inhibit the production of intracellular reactive oxygen species without creating obvious cytotoxic effects, and protect HT-29 cells against $\mathrm{H}_{2} \mathrm{O}_{2}$ injury evidenced by the significant decrease of the $\mathrm{Bcl}$-2-associated $\mathrm{X}$ protein $(\mathrm{Bax}) / \mathrm{B}$-cell lymphoma 2 (Bcl-2) ratio and heat shock protein 70 expression, increase of superoxide dismutase and glutathione peroxidase activities, and decrease of malondialdehyde level of HT-29 cells damaged by $\mathrm{H}_{2} \mathrm{O}_{2}$. It was speculated that L. plantarum Y44 protect HT-29 cells against oxygen radical injury through scavenging reactive oxygen species and activating intracellular antioxidant enzymes. A significant correlation was observed among the results of the hydroxyl radical scavenging assay, protection assay for HT-29 cells against $\mathrm{H}_{2} \mathrm{O}_{2}$ injury, and the cellular antioxidant assay. The findings indicated that L. plantarum Y44 could be a probiotic candidate with antioxidant properties and combining several chemical antioxidant methods and antioxidant cellular models could be an effective procedure to screen lactobacilli strains with antioxidant activity.
\end{abstract}

Received April 28, 2018.

Accepted August 2, 2018

${ }^{1}$ Corresponding author: tyfjq@aliyun.com
Key words: Lactobacillus, antioxidant activity, chemical antioxidant method, cellular antioxidant method

\section{INTRODUCTION}

Oxidative stress is caused by increased accumulation of reactive oxygen species (ROS) and is the cause of various chronic human diseases (Elfahri et al., 2016). Consequently, it is pivotal to protect the human body from attack by ROS (González-Manzano et al., 2012). Various chemical synthetic antioxidants have been used for years; however, their safety and long-term effects have been questioned (Das and Goyal, 2015). Natural antioxidants are now more in line with demand.

Lactobacilli strains are widespread in nature and possess many health-promoting activities, as well as a long safe history of being consumed by human beings (Guarner and Malagelada, 2003). Their role as an antioxidant is being investigated in depth. Lactobacillus acidophilus ATCC 4356 was capable of inhibiting linoleic acid peroxidation, scavenging 1,1-diphenyl2-picrylhydrazyl (DPPH) free radical activity, and protecting plasma lipid against oxidation (Lin and Chang, 2000). Lactobacillus fermentum E3 and L. fermentum E18 isolated from a healthy child had high survival rate in the presence of ROS, such as $\mathrm{H}_{2} \mathrm{O}_{2}$, $\mathrm{O}_{2}^{-}$, and ${ }^{\bullet} \mathrm{OH}$, and possessed Mn-superoxide dismutase (SOD) activity (Kullisaar et al., 2002). Lactobacillus casei Zhang could increase SOD, and glutathione peroxidase $(\mathbf{G P x})$ activity, decrease malondialdehyde (MDA) levels of the plasma and liver in rats to alleviate oxidative stress induced by endotoxin and D-galactosamine, respectively (Zhang et al., 2010; Wang et al., 2013). Lactobacillus plantarum CCFM10 could alleviate D-galactose-induced oxidative stress via regulating intestinal flora of mice (Zhao et al., 2018). The antioxidant activity mechanisms of lactobacilli strains could be roughly assigned to following categories: producing antioxidant metabolites and enzymes to scavenge ROS, upregulating antioxidant enzymes activities of the host, 
downregulating enzymes activities related to ROS production of the host, and regulating antioxidant-related signaling pathways of the host and the host's intestinal flora (Amaretti et al., 2013; Ianniello et al., 2015; Wang et al., 2017).

The antioxidant activity of lactobacilli strains was usually measured by chemical methods, such as hydroxyl, superoxide, and DPPH radical scavenging activity. Despite wide usage of chemical antioxidant activity assays, their ability to confirm in vivo activity is questioned (Wolfe and Liu, 2007). Furthermore, the role of antioxidants is not only scavenging free radicals, but also inhibiting free radical production and activating antioxidative systems (Niki, 2010). Xing et al. $(2015 \mathrm{a}, \mathrm{c})$ compared different antioxidant methods in assays for antioxidant activity of lactobacilli strains, and no significant relationships between DPPH method and cell method were established. Schaich et al. (2015) indicated that each antioxidant activity assay has a specific target, which has its own merits and limitations. Although animal models and human studies are a more appropriate method, they are more suitable for verifying the antioxidant activity of a single strain than for screening. Therefore, more research is needed to compare different methods and evaluate the antioxidant properties of probiotics. Some of the lactic acid bacteria strains isolated from fish intestines have shown antioxidant and anti-inflammatory properties, indicating probiotic potential (Kuda et al., 2014). We would like to assess and compare the antioxidant activity of lactobacilli strains by using different antioxidant methods.

In this study, the antioxidant activities of some lactobacilli strains were examined first by chemical methods, and furthermore by cellular antioxidant models to find lactobacilli strains with antioxidant activity and compare the efficiency of different antioxidant methods to find a suitable method of determining antioxidant activity.

\section{MATERIALS AND METHODS}

\section{Lactobacilli Strains}

Lactobacilli strains tested in this study were isolated from traditional fermented food in Liaoning province, China, stored in de Man, Rogosa, and Sharpe (MRS) medium (AOBOX Biotechnology, Qingdao, China) containing $25 \%$ glycerol at $-80^{\circ} \mathrm{C}$ at the Dalian Probiotics Function Research Key Laboratory. These lactobacilli strains were identified according to their characteristics of Gram staining, catalase assay, morphology, and 16S rRNA gene sequence analysis.

\section{Screening Lactobacilli Strains with DPPH Free Radical Scavenging Activity}

Preparation of samples was performed according to Chen et al. (2014). The lactobacilli strains were cultured in MRS broth (AOBOX Biotechnology) at $37^{\circ} \mathrm{C}$ for 18 $\mathrm{h}$. The intact cells of lactobacilli strains, sub-cultured and grown again at 37 for $18 \mathrm{~h}$, were harvested by centrifugation at 2,010 $\times g$ for $10 \mathrm{~min}, 4^{\circ} \mathrm{C}$ (Eppendorf, Hamburg, Germany). Cell pellets were washed twice with PBS (pH 7.4, Gibco Life Technologies, Grand Island, NY) and suspended in PBS. Cell number were adjusted to approximately $1.0 \times 10^{9} \mathrm{cfu} / \mathrm{mL}$, which were regarded as the sample in the following test.

The lactobacilli strains with antioxidant activity were screened by measuring their DPPH (Sigma-Aldrich, St. Louis, MO) free radical scavenging activity according to the method of Kao and Chen. (2006), with some modifications. Briefly, $1.0 \mathrm{~mL}$ of sample was added to $1.0 \mathrm{~mL}$ of DPPH-ethanol solution (0.02 $\mathrm{m} M)$. The mixture was mixed and incubated at $25^{\circ} \mathrm{C}$ in the dark for $30 \mathrm{~min}$. The control group included PBS and DPPH-methanol solution. The blank group contained sample and ethanol. The optical absorbance at $517 \mathrm{~nm}$ of supernatant was measured in triplicate by a Multiskan GO microplate reader (Thermo Fisher Scientific, Waltham, MA) after centrifugation at 2,010 $\times g$ for 10 min. Lactobacillus rhamnosus GG (ATCC 53103 ; LGG) was used as positive control. The DPPH scavenging activity was defined as

$$
\begin{gathered}
\text { scavenging activity }(\%)= \\
{\left[1-\left(\mathrm{A}_{\text {sample }}-\mathrm{A}_{\text {blank }}\right) / \mathrm{A}_{\text {control }}\right] \times 100 \%,}
\end{gathered}
$$

where $A_{\text {sample }}$ is the optical absorbance at $517 \mathrm{~nm}$ of the sample group, $A_{\text {blank }}$ is the optical absorbance at 517 $\mathrm{nm}$ of the blank group, and $\mathrm{A}_{\text {control }}$ is the absorbance of the control group.

\section{Transit Tolerance of Selected Lactobacilli Strains}

Simulated gastric juice and intestinal juice were prepared according to the method described by Bao et al. (2010). Briefly, the test cultures (1\%) were separately inoculated into simulated gastric juice at $\mathrm{pH} 2.5$. The mixtures were mixed for $10 \mathrm{~s}$ and incubated at $37^{\circ} \mathrm{C}$. Gastric transit tolerance was studied by determining total viable counts in gastric juice withdrawn at $3 \mathrm{~h}$. After $3 \mathrm{~h}$ of incubation in gastric juice, $0.5 \mathrm{~mL}$ of culture was inoculated into $4.5 \mathrm{~mL}$ of simulated intestinal juice $(\mathrm{pH} 8.0)$ at $37^{\circ} \mathrm{C}$. The intestinal transit tolerance was studied by determining the total viable counts in 
intestinal juice withdrawn at $8 \mathrm{~h}$. The viable counts of selected lactobacilli strains were determined by a pour plate method using MRS agar after appropriate serial dilution. The MRS agar plates were incubated at $37^{\circ} \mathrm{C}$ for $48 \mathrm{~h}$ and the colony-forming units were estimated. Survival rate was calculated according to the following equation:

survival rate $(\%)=\left(\log\right.$ cfu $\mathrm{N}_{1} / \log$ cfu $\left.\mathrm{N}_{0}\right) \times 100 \%$,

where $\mathrm{N}_{1}$ represents the total viable count of lactobacilli strains after treatment by simulated gastrointestinal juices, and $\mathrm{N}_{0}$ represents the total viable count of lactobacilli strains before treatment.

\section{Oxygen Radical Absorbance Capacity Assay}

The oxygen radical absorbance capacity (ORAC) assay is a widely used method to analyze total antioxidants. The ORAC assay was evaluated as described by $\mathrm{Li}$ et al. (2017), with some modifications. Briefly, the sample concentration was diluted to $10^{8} \mathrm{cfu} /$ $\mathrm{mL}$. Then $20 \mu \mathrm{L}$ of sample was added into the wells of black 96-well plates with a clear bottom (Corning Inc., Corning, NY), and $20 \mu \mathrm{L}$ of fluorescein (SigmaAldrich) at a final concentration of $0.96 \mu M$ was added. The mixture was automatically shaken and preincubated for $20 \mathrm{~min}$ at $37^{\circ} \mathrm{C}$. Finally, $140 \mu \mathrm{L}$ of $12.8 \mathrm{mM}$ 2,2'-azobis(2-methylpropionamidine) dihydrochloride (ABAP, Sigma-Aldrich) was added to each well. The fluorescence intensity was measured and recorded using SpectraMax M2 microplate reader (Molecular Devices, Sunnyvale, CA) at an excitation of $485 \mathrm{~nm}$ and an emission of $538 \mathrm{~nm}$ for 60 cycles every 2 min. Trolox was used as the positive control. The ORAC values for lactobacilli strains were expressed as the equivalent amount of Trolox with the same antioxidant activity $(\mathrm{m} M)$ for triplicate. Lactobacillus rhamnosus GG was used as a positive control.

\section{Resistance to Hydrogen Peroxide Assay}

The resistance of lactobacilli strains to $\mathrm{H}_{2} \mathrm{O}_{2}$ was determined as described by Li et al. (2012), with some modifications. Then overnight cultures of lactobacilli strains were inoculated at $2 \%$ (vol/vol) into MRS both as control group, and MRS broth containing 0.5 or 1.0 $\mathrm{m} M \mathrm{H}_{2} \mathrm{O}_{2}$ separately as a sample group. The control group and the sample group were incubated at $37^{\circ} \mathrm{C}$ for $8 \mathrm{~h}$. The growth of lactobacilli strains was measured in triplicate by a Multiskan GO microplate reader (Thermo Fisher Scientific) at $600 \mathrm{~nm}$. Lactobacillus rhamnosus GG was used as a positive control. The survival rate (\%) of the lactobacilli strains damaged by $\mathrm{H}_{2} \mathrm{O}_{2}$ was calculated as follows:

$$
\text { survival rate }(\%)=\left(\mathrm{A}_{\text {sample }} / \mathrm{A}_{\text {control }}\right) \times 100 \%,
$$

where $A_{\text {sample }}=$ the optical absorbance of sample group at $600 \mathrm{~nm}$, and $\mathrm{A}_{\text {control }}=$ the optical absorbance of control group at $600 \mathrm{~nm}$.

\section{Hydroxyl Free Radical Scavenging Activity Assay}

The hydroxyl free radical scavenging activity was analyzed according to the method of Li et al. (2013) with some modifications. Briefly, the reaction mixture containing $1.0 \mathrm{~mL}$ of PBS (20 mM, pH 7.4), $0.5 \mathrm{~mL}$ of 1,10-phenanthroline (2.5 mM, Sigma-Aldrich), $0.5 \mathrm{~mL}$ of $\mathrm{FeSO}_{4}(2.5 \mathrm{mM}), 0.5 \mathrm{~mL}$ of $\mathrm{H}_{2} \mathrm{O}_{2}(2.5 \mathrm{mM})$, and 0.5 $\mathrm{mL}$ of lactobacilli strain suspensions $\left(10^{9} \mathrm{cfu} / \mathrm{mL}\right)$ were incubated at $37^{\circ} \mathrm{C}$ for $60 \mathrm{~min}$. The optical absorbance at $536 \mathrm{~nm}$ of the mixture was measured in triplicate after centrifugation $(2,010 \times g, 10 \mathrm{~min})$. Lactobacillus rhamnosus GG was used as a positive control.

Hydroxyl radical scavenging activity is expressed as

$$
\begin{gathered}
\text { scavenging activity }(\%)= \\
\left(\mathrm{A}_{\text {sample }}-\mathrm{A}_{\text {control }}\right) /\left(\mathrm{A}_{\text {blank }}-\mathrm{A}_{\text {control }}\right) \times 100 \%,
\end{gathered}
$$

where $A_{\text {sample }}$ is the absorbance in the presence of the sample, $A_{\text {blank }}$ is the absorbance of the blank solution without the sample and Fenton reaction system, and $\mathrm{A}_{\text {control }}$ is the absorbance of the control solution in the absence of the sample.

\section{Cellular Antioxidant Activity Assay for Selected Lactobacilli Strains}

Cell Cytotoxicity Assay. Cytotoxicity of the lactobacilli strains was measured using the modified methylene blue assay (Xing et al., 2015a). Briefly, human colon cancer cell line HT-29 cells (Cell Bank of the Type Culture Collection of the Chinese Academy of Sciences, Shanghai, China) were routinely cultured at $37^{\circ} \mathrm{C}$ in a $5 \% \mathrm{CO}_{2}$ atmosphere in RPMI 1640 medium (Gibco Life Technologies) supplemented with $10 \%$ (vol/vol) heat-inactivated fetal bovine serum (Gibco Life Technologies). Cells were seeded at a density of $4 \times 10^{4}$ cells/well on a 96-well microplate (Corning Inc.) in $100 \mu \mathrm{L}$ of RPMI 1640 medium for $24 \mathrm{~h}$ at $37^{\circ} \mathrm{C}$. After washing with PBS twice, HT-29 cells were treated with $100 \mu \mathrm{L}$ of the sample $\left(10^{9} \mathrm{cfu} / \mathrm{mL}\right.$ of $\mathrm{Y} 3$ or Y44 dissolved in RPMI 1640 medium) or RPMI 1640 medium (control group) for up to $24 \mathrm{~h}$ at $37^{\circ} \mathrm{C}$. To assess cell viability, the cells were washed with PBS and 
then incubated with $50 \mu \mathrm{L} /$ well methylene blue $(98 \%$ Hanks' balanced salt solution, $0.67 \%$ glutaraldehyde, and $0.6 \%$ methylene blue) for $1 \mathrm{~h}$ at $37^{\circ} \mathrm{C}$. After the incubation, the cells were washed with deionized water until the water was clear, and $100 \mu \mathrm{L} /$ well elution $(49 \%$ PBS, $50 \%$ ethanol, and $1 \%$ acetic acid) was then added. Then microplate was shaken on a microplate oscillator (IKA, Wilmington, NC) for $20 \mathrm{~min}$. The absorbance was measured at $570 \mathrm{~nm}$. Different samples were compared with the control. A sample that resulted in more than $10 \%$ less absorbance than the control group was considered to be cytotoxic.

Cellular Antioxidant Activity Assay of Lactobacilli Strains. The cellular antioxidant activity (CAA) of the lactobacilli strains was evaluated according to the method of Wolfe and Liu (2007), with some modifications. The HT-29 cells were seeded at a density of $6 \times 10^{4}$ cells/well on a black 96-well microplate with clear bottom (Corning Inc.) in 100 $\mu \mathrm{L}$ of RPMI 1640 medium for $24 \mathrm{~h}$ at $37^{\circ} \mathrm{C}$ to reach $80 \%$ confluence, respectively. The cells were treated with $100 \mu \mathrm{L}$ of sample $\left(10^{9} \mathrm{cfu} / \mathrm{mL}\right.$ of $\mathrm{Y} 3$ or Y44 dissolved in RPMI 1640 medium) after rinsing with PBS, including $25 \mu \mathrm{M}$ of $2^{\prime}, 7^{\prime}$-dichlorofluorescin diacetate (DCFH-DA, Sigma-Aldrich) for up to $1 \mathrm{~h}$ at $37^{\circ} \mathrm{C}$. Quercetin final concentrations of 2, 4, 8, 16, and $32 \mu M$ were used to make a standard curve. Subsequently, the cells were washed with PBS and treated with $100 \mu \mathrm{L}$ of $600 \mu M$ ABAP (dissolved in Hanks' balanced salt solution). Fluorescence was measured with SpectraMax M2 microplate reader (Molecular Devices) for 13 cycles at 5 -min intervals $(\lambda \mathrm{ex}=485$ and $\lambda \mathrm{em}=538)$. The area under the curve of fluorescence versus time was integrated to calculate the CAA value of each sample after a blank subtraction from the fluorescent readings.

$$
\text { CAA value }(\text { unit })=\left[1-\left(\int \mathrm{SA} / \int \mathrm{CA}\right)\right] \times 100,
$$

where $\int \mathrm{SA}$ is the integrated area of the sample and JCA is the integrated area in the control curve. Cells treated with DCFH-DA were used as blank, whereas cells treated with DCFH-DA and ABAP were used as the control. Lactobacillus rhamnosus GG was used as the positive control. Quercetin was used in each experiment as a standard, and the CAA values (units) for lactobacilli strains were expressed as the equivalent amount of quercetin with the same antioxidant activity $(\mathrm{m} M)$.

\section{Protection of Lactobacilli Strains for HT-29 Cells Against $\mathrm{H}_{2} \mathrm{O}_{2}$ Injury}

Cell Viability Assay. Cell viability assay was carried out according to $\mathrm{Li}$ et al. (2013). Cells were added into wells of 96-well plates (Corning Inc.) at a density of $1.5 \times 10^{6}$ cells $/ \mathrm{mL}$ for $100 \mu \mathrm{L}$ and incubated to allow for cell attachment. After $24 \mathrm{~h}$ incubation, the growth medium was removed and cells were washed with PBS twice. Cells were pretreated with $100 \mu \mathrm{L}$ of sample $\left(10^{9}\right.$ $\mathrm{cfu} / \mathrm{mL}$ of Y3, Y44 dissolved in RPMI 1640 medium) for $2 \mathrm{~h}$. The $\mathrm{H}_{2} \mathrm{O}_{2}$ was prepared in the medium by several times of dilution before added. Then $100 \mu \mathrm{L}$ of $\mathrm{H}_{2} \mathrm{O}_{2}$ was added to induce oxidative stress at a final concentration of $150 \mu \mathrm{M}$ for another $22 \mathrm{~h}$. The damage was stopped by taking out cultured supernatants, and cells were washed with PBS twice. Cells with no $\mathrm{H}_{2} \mathrm{O}_{2}$ treatment served as the control group. Cells only with $\mathrm{H}_{2} \mathrm{O}_{2}$ treatment were served as the $\mathrm{H}_{2} \mathrm{O}_{2}$ group.

The HT-29 cells viability was measured in 96-well plates by theMTS method (Zhuetal., 2015). The3-(4,5-dimethylthiazol-2-yl)-5-(3-carboxymethoxyphenyl)-2-(4sulfophenyl)-2H-tetrazolium, inner salt (MTS, CellTiter 96 AQueous One Solution Cell Proliferation Assay, Promega, Madison, WI) was added to wells at $20 \mu \mathrm{L}$ with $100 \mu \mathrm{L}$ of fresh medium. After $4 \mathrm{~h}$ incubation, the absorbance was measured by a Multiskan GO microplate reader (Thermo Fisher Scientific) at $490 \mathrm{~nm}$. Cell viability was expressed as mean percentage of viable cells compared with the control group. Lactobacillus rhamnosus GG was used as the positive control.

Western Blot Assay. The Western blot analysis was carried out as Jiang et al. (2016), with some modifications. The HT-29 cells were added into wells of 6 -well plates (Corning Inc.) at a density of $1.5 \times$ $10^{6}$ cells $/ \mathrm{mL}$ for $2 \mathrm{~mL}$ and incubated to allow for cell attachment. After $24 \mathrm{~h}$ incubation, the growth medium was removed and cells were washed with PBS twice. Cells were pretreated with a $1-\mathrm{mL}$ sample $\left(10^{9} \mathrm{cfu} / \mathrm{mL}\right.$ of Y44 dissolved in RPMI 1640 medium) for $2 \mathrm{~h}$. The $\mathrm{H}_{2} \mathrm{O}_{2}$ was prepared in the medium by diluting several times before addition. Then $1 \mathrm{~mL}$ of $\mathrm{H}_{2} \mathrm{O}_{2}$ was added to induce oxidative stress at a final concentration of 150 $\mu M$ for another $22 \mathrm{~h}$. The damage was stopped by taking out cultured supernatants, and cells were washed with PBS twice. Cells were harvested in $1 \mathrm{~mL}$ of cold PBS, then lysed in RIPA buffer (Solarbio Life Science, Beijing, China) with 1\% PMSF (Solarbio Life Science). Cell lysates were shaken 10 min by ultrasound assistance to facilitate protein extraction. Protein concentrations of the lysates were determined using the BCA protein assay kit (Solarbio Life Science). Equal amounts of protein from each cell lysate was subjected to $15 \%$ (wt/vol) SDS-PAGE and transferred to polyvinylidene difluoride membranes. The membranes were blocked for $1 \mathrm{~h}$ with PBS containing of $0.05 \%$ Tween 20 and containing $5 \%$ nonfat milk at room temperature. Membranes were incubated overnight at $4^{\circ} \mathrm{C}$ with antibodies against Bcell lymphoma 2 (Bcl-2), Bcl-2-associated X protein 
Table 1. Survival rate (\%) of lactobacilli strains in simulated gastric juice and intestinal juice ${ }^{1}$

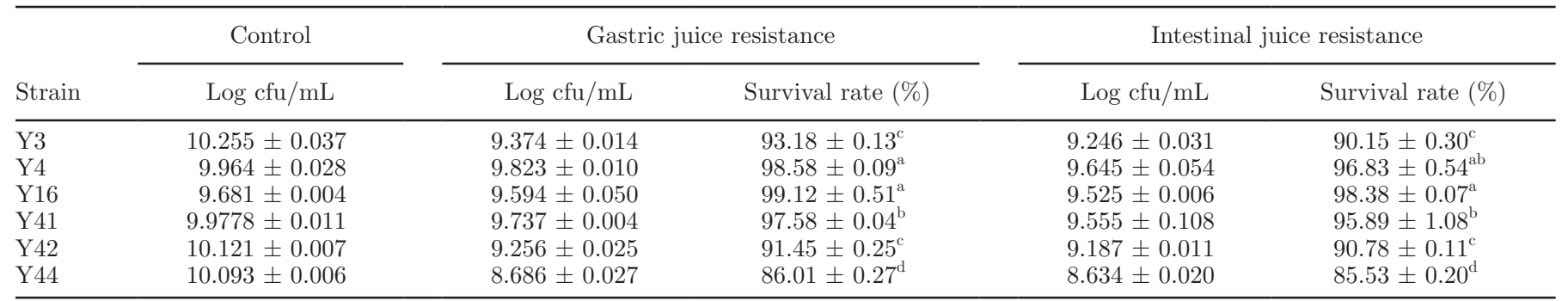

${ }^{\mathrm{a}-\mathrm{d}}$ Different superscripts within a column indicate a significant difference at the 0.05 level.

${ }^{1}$ The results are expressed as means $\pm \mathrm{SD}(\mathrm{n}=3)$.

(Bax), heat shock protein (Hsp) 70, and $\beta$-actin (all in 1:1,000 dilutions in primary antibody dilution buffer, Beyotime Institute of Biotechnology, Shanghai, China) followed by the corresponding horseradish peroxidaselabeled secondary antibodies (all in 1:2,000 dilutions in 1\% BSA, Beyotime Institute of Biotechnology) for 1 $\mathrm{h}$ at room temperature. Protein bands were visualized by BeyoECL star Kit (Beyotime Institute of Biotechnology) according to the protocols. Bands were then scanned and quantified by ImageJ software (National
Institutes of Health, Bethesda, MD). The expression of human $\beta$-actin was used as an internal standard control. All measurements were conducted in triplicate.

SOD, GPx, and MDA Assays. The SOD, GPx, and MDA assays were according to Zhang et al. (2013). The HT-29 cells were added into wells of 12 -well plates (Corning Inc.) at a density of $1.5 \times 10^{6}$ cells $/ \mathrm{mL}$ for 1 $\mathrm{mL}$ and incubated to allow for cell attachment. After $24 \mathrm{~h}$ incubation, the growth medium was removed and cells were washed with PBS twice. Cells were pretreated

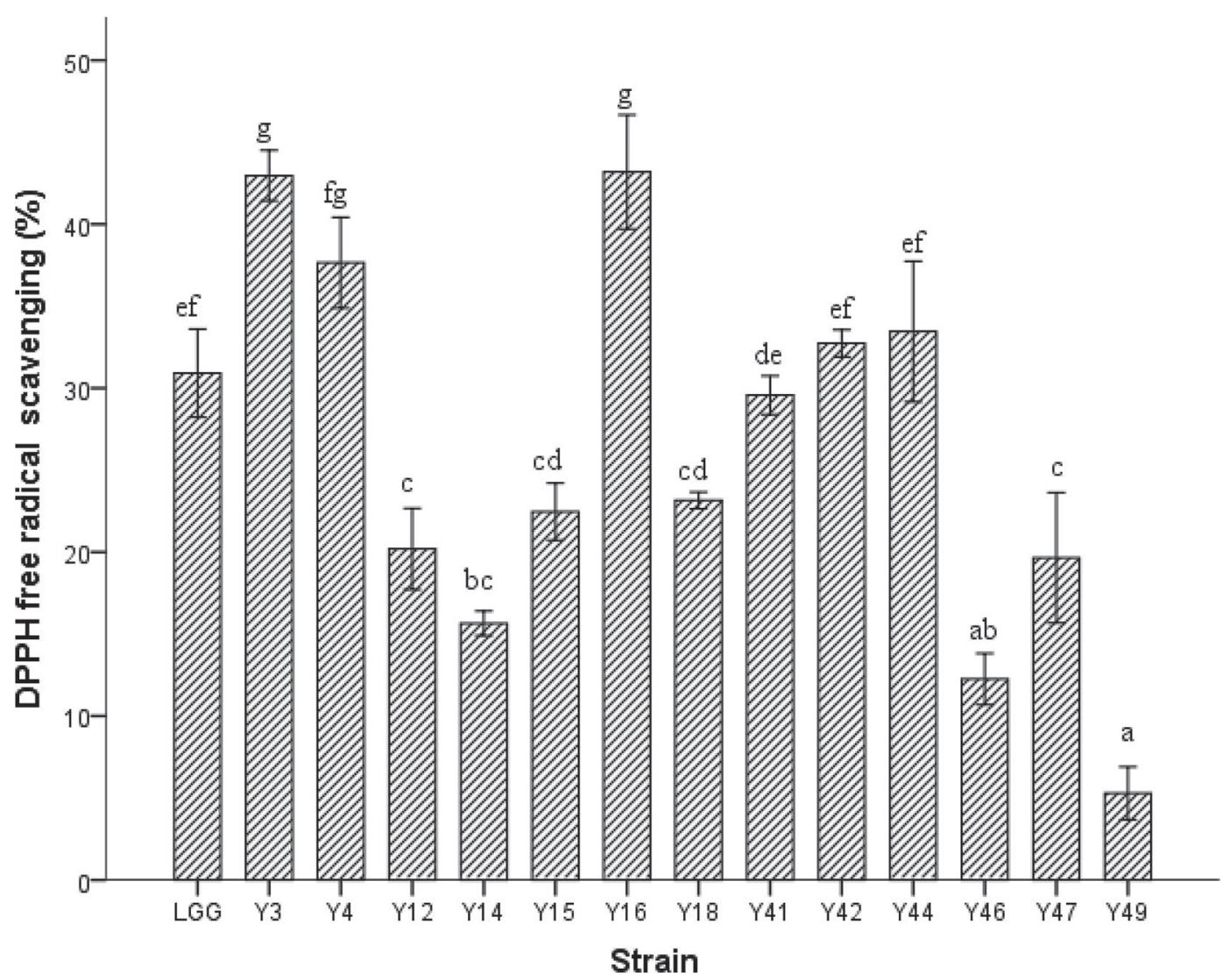

Figure 1. Scavenging 1,1-diphenyl-2-picrylhydrazyl (DPPH) free radical activity of lactobacilli strains. The results are expressed as means $\pm \mathrm{SD}(\mathrm{n}=3)$. Different lowercase letters $(\mathrm{a}-\mathrm{g})$ on columns indicate a significant difference at the 0.05 level. 
with $500 \mu \mathrm{L}$ of sample $\left(10^{9} \mathrm{cfu} / \mathrm{mL}\right.$ of $\mathrm{Y} 3$, Y44 dissolved in RPMI 1640 medium) for $2 \mathrm{~h}$. The $\mathrm{H}_{2} \mathrm{O}_{2}$ was prepared in the medium by several times of dilution before being added. Then $500 \mu \mathrm{L}$ of $\mathrm{H}_{2} \mathrm{O}_{2}$ was added to induce oxidative stress at the final concentration of $150 \mu M$ for another $22 \mathrm{~h}$. The damage was stopped by taking out cultured supernatants, and cells were washed with PBS twice. Cells were suspended in $1 \mathrm{~mL}$ of buffer $(50 \mathrm{mM}$ Tris-HCl pH 8.0, $50 \mathrm{~m} M$ EDTA $\mathrm{Na}_{2}, 0.2 M \mathrm{NaCl}, 1 \%$ Triton X-100) to lyse cells, and the yielded cell homogenate was immediately centrifuged $\left(6,915 \times g, 4^{\circ} \mathrm{C}\right.$ for $15 \mathrm{~min})$. The afforded supernatant was stored at $-80^{\circ} \mathrm{C}$ before the assays. The SOD, GPx, and MDA assays were determined using the detection kit provided by Nanjing Jiancheng Bioengineering Institute (Nanjing, China). Lactobacillus rhamnosus GG was used as the positive control.

\section{Statistics Analysis}

All of the tests were performed in triplicate, and data are presented as mean \pm standard deviation. One-way ANOVA was performed with SPSS (version 20.0, SPSS
Inc., Chicago, IL) to verify significant differences between samples. The results were considered significant when $P<0.05$.

\section{RESULTS AND DISCUSSION}

\section{Lactobacilli Strains with Scavenging DPPH Free Radical Activity}

Some lactobacilli strains are regarded as probiotic bacteria due to their ability to improve the health of hosts (Tang et al., 2016). Accumulated evidence suggests that some lactobacilli strains exerted antioxidant activity benefiting host health after they colonized and propagated in the human gastrointestinal tract (Kanno et al., 2012; Ren et al., 2014). In this study, 13 of the tested strains exhibited DPPH scavenging activity as shown in Figure 1. The strains Y3, Y4, Y16, Y41, Y42, and Y44 had higher or same scavenging DPPH free radical activity compared with that of LGG. The strains Y3, Y4, and Y16 belonged to Lactobacillus casei species, and Y41, Y42, and Y44 belonged to Lactobacillus plantarum species.

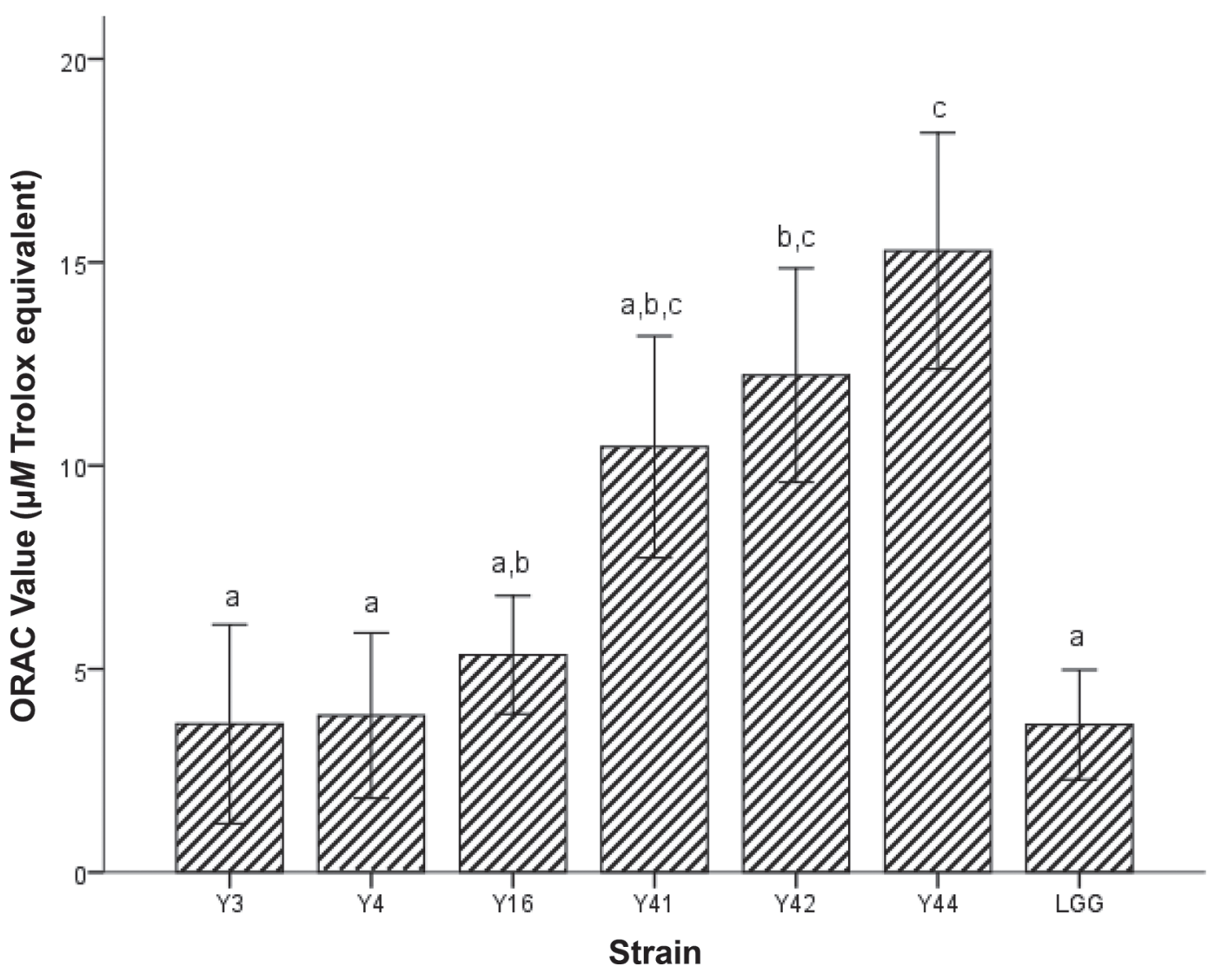

Figure 2. Oxygen radical absorbance capacity (ORAC) value of lactobacilli strains in $10^{8} \mathrm{cfu} / \mathrm{mL}$. The results are expressed as means $\pm \mathrm{SD}$ $(\mathrm{n}=3)$. Different lowercase letters $(\mathrm{a}-\mathrm{c})$ on columns indicate a significant difference at the 0.05 level. 
Lactobacilli strains are required to stay alive in the conditions of gastric juice and intestinal juice, to transfer antioxidant activity to the host (Bao et al., 2012). The results of the resistance of 6 lactobacilli strains to gastric juice and intestinal juice are shown in Table 1 . The 6 lactobacilli strains exhibited fairly good tolerance, in which survival rates ranged from 98.38 to 85.53\%. Particularly, survival rates of Y4, Y16, and Y41 were higher than $95.89 \%$, which were significantly higher than those of other lactobacilli strains $(P<$ $0.05)$. This indicated that all 6 of the lactobacilli strains could keep abundant viable counts to colonize in the gastrointestinal tract.

The free radical scavenging activity of DPPH is mainly attributed to electron or hydrogen-donating ability, and the mechanism may be different from other antioxidant models (Li et al., 2015). Mishra et al. (2015) recommended a universal method giving unambiguous results is to use multiple methods instead of one. (Mishra et al., 2015). In this case, other common 3 models, ORAC, resistance to $\mathrm{H}_{2} \mathrm{O}_{2}$, and hydroxyl free radical scaveng- ing activity would be used for the determination of the antioxidant activity of the lactobacilli strains.

The 6 lactobacilli strains Y3, Y4, Y16, Y41, Y42, and Y44, with better DPPH radical scavenging activity and gastrointestinal juice resistance, were selected for further antioxidant study including ORAC, resistance to hydrogen peroxide, and hydroxyl free radical scavenging activity.

\section{ORAC Assay}

The ORAC assay is one of the most widely used methods in determination of total antioxidant activity, which have been applied to detect antioxidant activity in fruits, vegetables, phytochemicals, and bioactive compounds in vitro (Wolfe and Liu, 2008; Song et al., 2010). In this study, the ORAC assay was used to assess the antioxidant activities of the 6 lactobacilli strains. All 6 selected lactobacilli strains exhibited ORAC values, demonstrated by Trolox equivalents, from 3.62 to 15.27 $\mu \mathrm{M}$ as shown in Figure 2. Lactobacillus plantarum

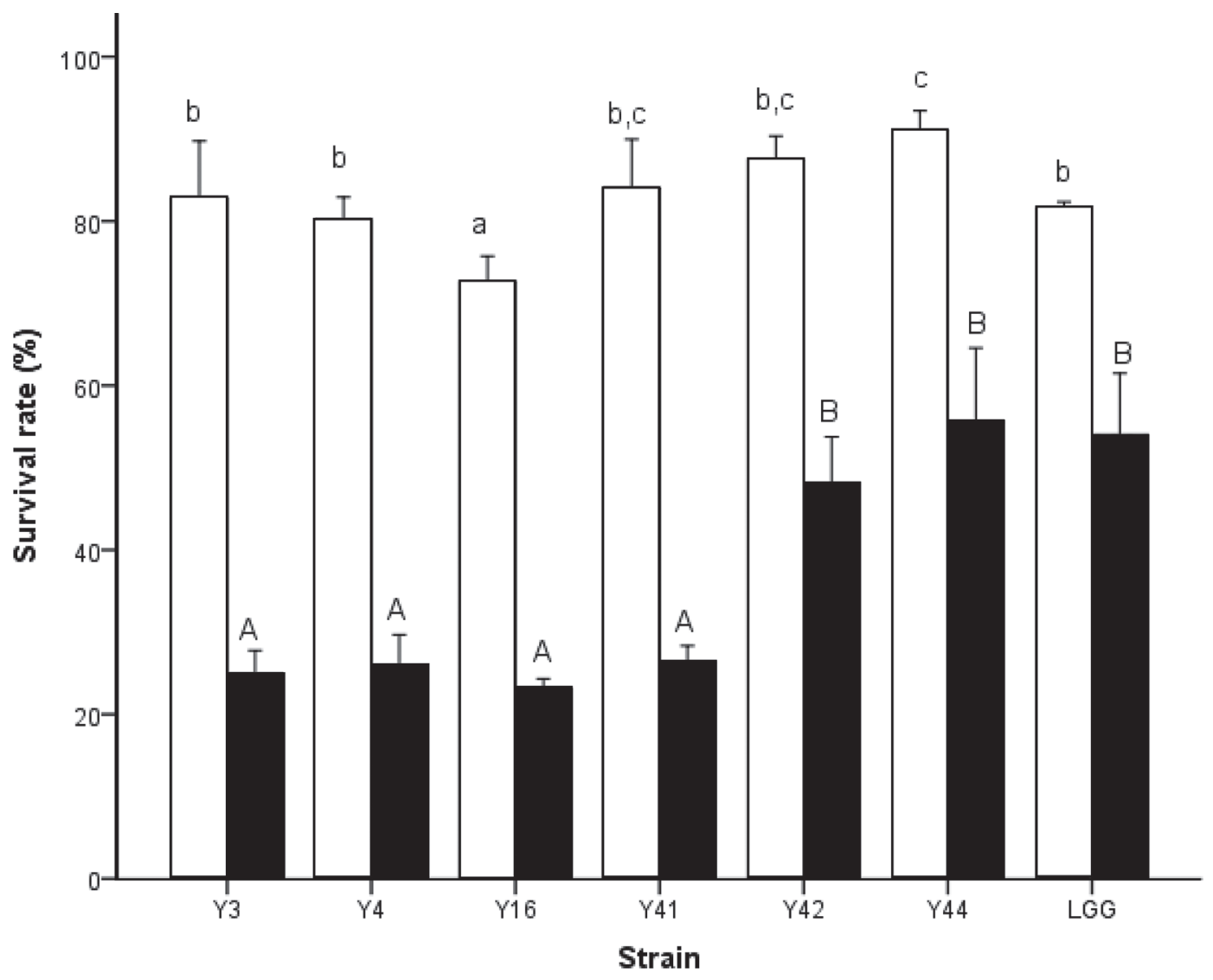

Figure 3. Survival rate (\%) of lactobacilli strains treated with $\mathrm{H}_{2} \mathrm{O}_{2}$ at $0.5 \mathrm{~m} M$ (white bars) and $1.0 \mathrm{~m} M$ (black bars). The results are expressed as means $\pm \mathrm{SD}(\mathrm{n}=3)$. Different lowercase letters $(\mathrm{a}-\mathrm{c})$ on columns indicate a significant difference at the 0.05 level in the $0.5 \mathrm{~m} M$ hydrogen peroxide treatment. Different uppercase letters $(\mathrm{A}, \mathrm{B})$ on columns indicate a significant difference at the 0.05 level in the $1.0 \mathrm{~m} M$ hydrogen peroxide treatment. 
Y44 showed the highest ORAC value among the 6 selected lactobacilli strains, indicating that L. plantarum Y44 could inhibit fluorescein oxidation by ABAP. In the ORAC assay, the fluorescent loss of fluorescein as probes is followed over time with ABAP oxidation (Niki, 2010). In this study, concentrations of lactobacilli strains were diluted to $10^{8} \mathrm{cfu} / \mathrm{mL}$ to avoid their turbidity affecting fluorescence intensity and obtain normal fluorescence intensity, according to Saide and Gilliland (2005).

\section{Resistance to $\mathrm{H}_{2} \mathrm{O}_{2}$}

Hydrogen peroxide is a weak oxidant that could permeate the cell membrane easily and cause oxidative damage to DNA, proteins, and lipids (Mishra et al., 2015). In this study, the 6 lactobacilli strains were detected to be catalase-negative, meaning that the strains could not degrade $\mathrm{H}_{2} \mathrm{O}_{2}$ directly. As shown in Figure $3, \mathrm{H}_{2} \mathrm{O}_{2}$ at different concentration could inhibit growth of the 6 lactobacilli strains. When strains were exposed to $0.5 \mathrm{mM} \mathrm{H} \mathrm{H}_{2} \mathrm{O}_{2}$, survival rates ranged from
72.67 to $91.05 \%$. Survival rates of the strains Y3, Y4, Y16, and Y41 were lower than $30 \%$ when exposed to $1.0 \mathrm{mM} \mathrm{H} \mathrm{H}_{2} \mathrm{O}_{2}$, whereas survival rates of $\mathrm{Y} 42$ and $\mathrm{Y} 44$ were more than $50 \%$ in the same condition $(P<0.05)$ as LGG. Most of the lactobacilli strains are regarded as catalase-negative. Only few species possessed catalase or pseudo-catalase activity, such as L. plantarum ATCC 14431 and L. plantarum MA2, which could help them from oxidative stress (Kono and Fridovich, 1983; Tang et al., 2017). Even though most of the lactobacilli strains did not possess catalase activity, L. plantarum K46 and L. plantarum KCC-24 also showed moderate resistance against various concentrations of $\mathrm{H}_{2} \mathrm{O}_{2}$ (Arasu et al., 2014; Vijayakumar et al., 2015). Some researchers further explored how catalase-negative lactobacilli strains resist $\mathrm{H}_{2} \mathrm{O}_{2}$ induced oxidative stress. Cappa et al. (2005) discovered that overexpression of uvrA gene of $L$. helveticus CNBL1156 could be conducive to L. helveticus CNBL1156 survival in the $\mathrm{H}_{2} \mathrm{O}_{2}$. Lactobacillus plantarum WCFS1 could express thioredoxin, which catalyzes the intracellular redox reaction and relieves oxidative stress induced by $\mathrm{H}_{2} \mathrm{O}_{2}$ (Serrano

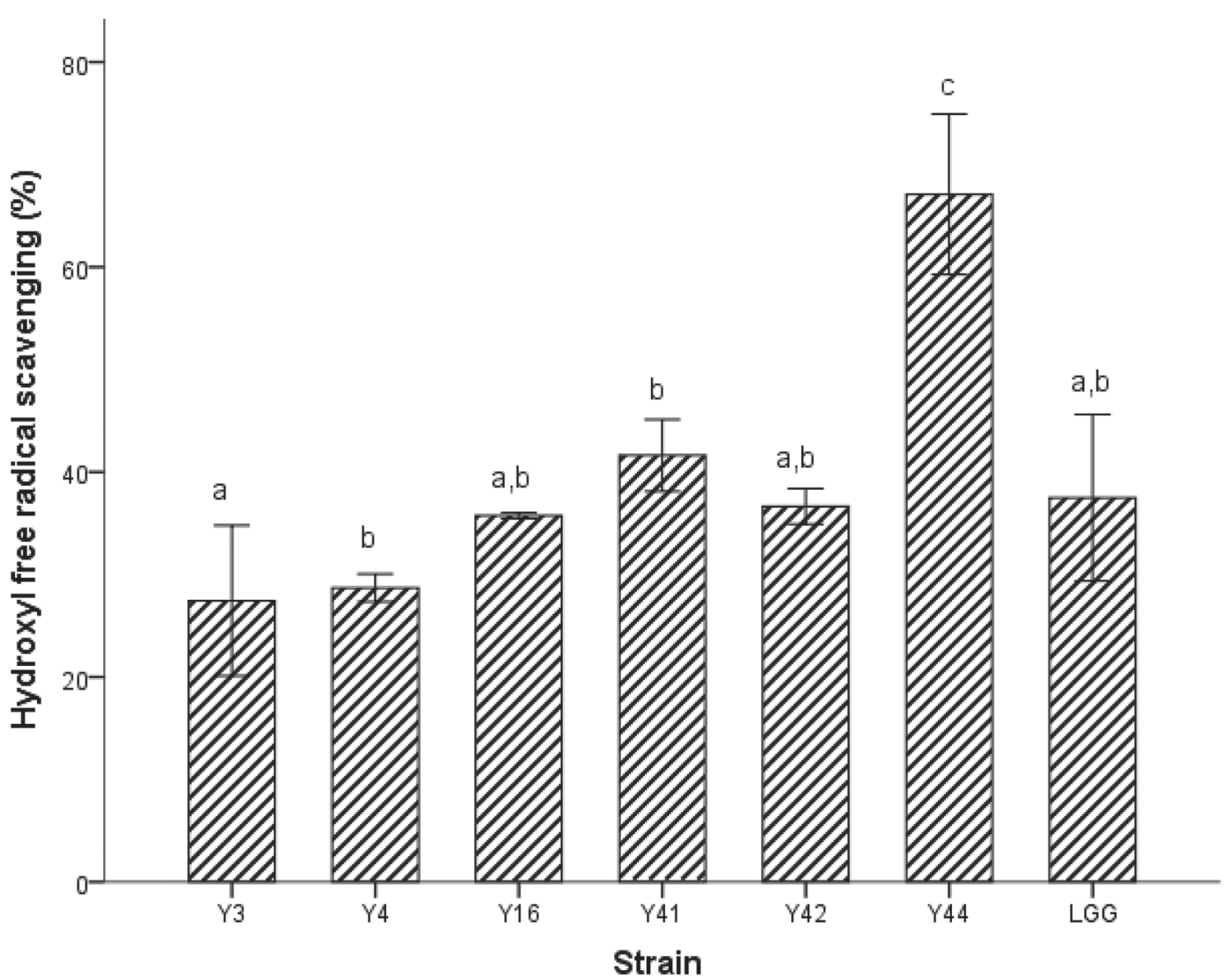

Figure 4. Scavenging hydroxyl free radical activities of lactobacilli strains. The results are expressed as means \pm SD $(\mathrm{n}=3$ ). Different lowercase letters $(\mathrm{a}-\mathrm{c})$ on columns indicate a significant difference at the 0.05 level. 
et al., 2007). Why L. plantarum Y44 had a higher survival rate when exposed to hydrogen peroxide needs to be further explored.

\section{Scavenging Hydroxyl Free Radical Activity}

Among the ROS, the hydroxyl radical is the most reactive radical and can easily lead to lipid peroxidation and react with biomolecules of the cells (Xiao et al., 2015). Six lactobacilli strains showed different hydroxyl free radical scavenging activity as shown in Figure 4. Lactobacillus plantarum Y44 showed significant higher hydroxyl free radical scavenging activity than other lactobacilli strains $(P<0.05)$.

Through research about ORAC value, resistance to $\mathrm{H}_{2} \mathrm{O}_{2}$ and hydroxyl free radical scavenging activity of the 6 lactobacilli strains, L. plantarum Y44 was found to have higher antioxidant potential and was selected for further cell antioxidant assays. Lactobacillus casei Y3, showing weaker antioxidant activity among the 6 lactobacilli strains, was also subjected to cell model antioxidant assay with L. plantarum Y44 and L. rhamnosus GG. Cell culture models for antioxidant activity assay were developed, with the advantages of considering the ROS scavenging activity, antioxidant and detoxifying enzyme regulation, cell signaling, and gene expression modulation, and not just their capacity as reducing agents (López-Alarcón, and Denicola, 2013).

\section{CAA Assay}

The CAA assay is a more biologically relevant method than the popular chemical antioxidant activity assays because it accounts for some aspects of uptake, metabolism, and location of antioxidant compounds within cells (Wolfe and Liu, 2007). Xing et al. (2015a) applied a CAA assay to assess the antioxidant activities of lactobacilli strains and pointed out that the CAA assay could be a better choice to determine the antioxidant activities of lactobacilli strains than chemical antioxidant assays.

In this study, CAA assay was carried out by using human colon cancer cell lines HT-29 to simulate human intestinal tract epithelial cells. The results of cell cytotoxicity assay showed that quercetin, L. plantarum Y44, and L. casei Y3 did not possess cell cytotoxicity to HT-29 cells (data not shown). The CAA of quercetin at different concentrations was determined by monitoring its ability to prevent ABAP-induced oxidation in HT-29 cells. A notable dose-dependent inhibition of the ABAP-induced increase in fluorescence was observed following treatment with quercetin (Figure 5A). The fluorescence intensities decreased with the pretreatment of different concentrations of quercetin. The concentration of quercetin and the CAA value showed the dose-dependent response, as shown in Figure 5B. A standard curve was also made by the regression equation: $y=24.381 \ln (x)+3.8018$, which had a statistically significant correlation coefficient of 0.9986 , where $y$ is CAA value (units) and $x$ is the concentration of quercetin in units of $\mathrm{m} M$. Therefore, CAA values of lactobacilli strains could be expressed as the equivalent amount of quercetin with the same CAA value, due to good nonlinear relationships between the quercetin standard and the CAA value.

The CAA assay was used to quantitatively evaluate the antioxidant activities of the lactobacilli strains in
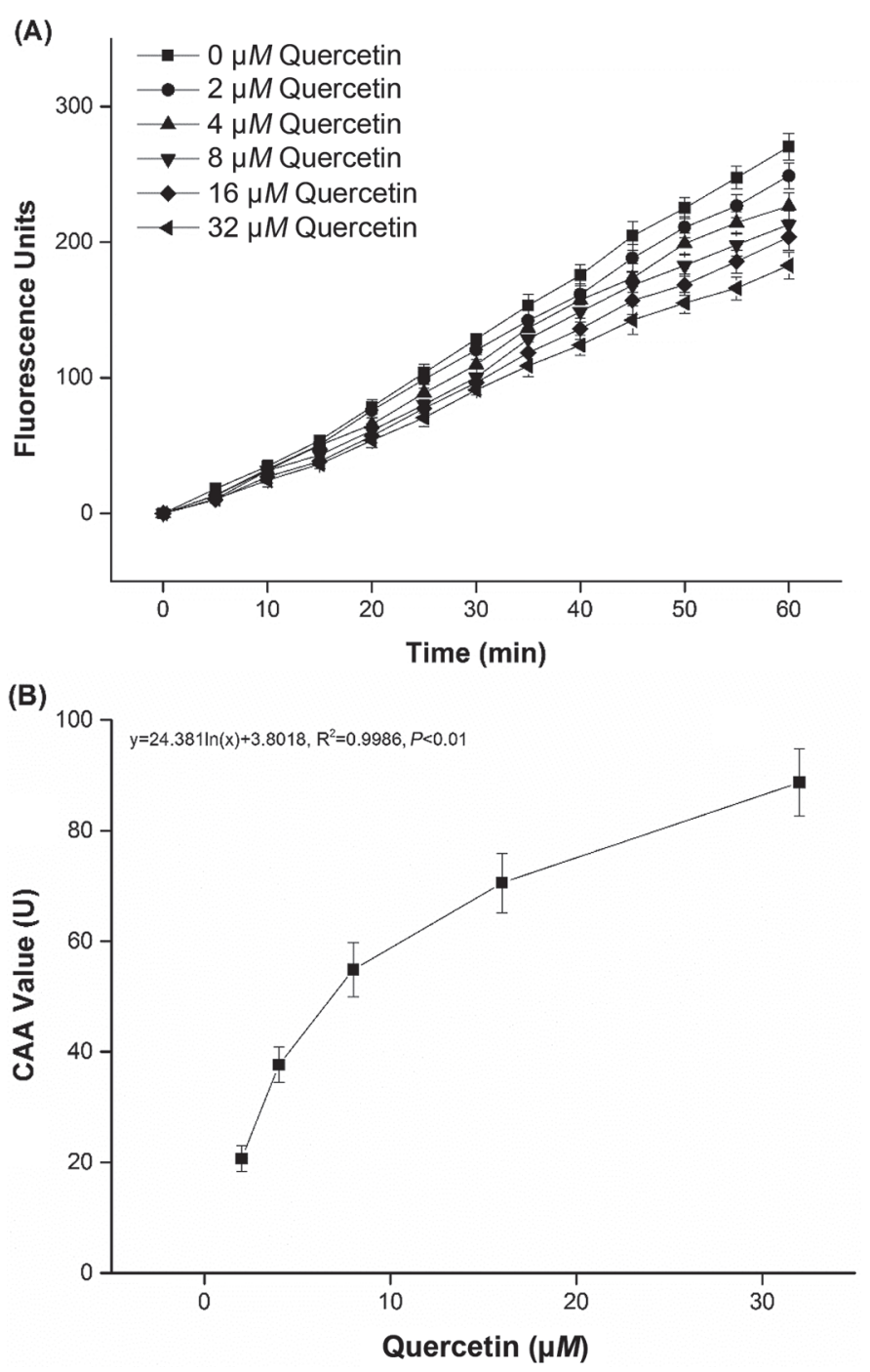

Figure 5. Peroxyl radical-induced oxidation of $2^{\prime}, 7^{\prime}$-dichlorofluorescin (DCFH) to oxidized DCFH in HT-29 cells and the inhibition of oxidation by the quercetin over time (A). Dose-response stranded curves for inhibition of peroxyl radical-induced DCFH oxidation by quercetin (B). The results are expressed as mean $\pm \mathrm{SD}(\mathrm{n}=6)$. CAA $=$ cellular antioxidant activity assay. 
HT-29 cells. In the CAA assay, DCFH-DA diffused into the cell by cellular esterases cleaved the diacetate to form the more polar DCFH (2',7'-dichlorofluorescin). The ABAP, which was able to diffuse into cells, spontaneously decomposed to form peroxyl radicals to oxidize the intracellular DCFH to the fluorescent DCF (oxidized DCFH). Lactobacilli strains could prevent oxidation of DCFH and reduce the formation of DCF. All 3 lactobacilli strains reduced the DCF fluorescence in a time-dependent manner, as shown in Figure 6A. During the $60 \mathrm{~min}, \mathrm{Y} 3, \mathrm{Y} 44$, and LGG inhibited the oxidation, with lower fluorescence intensities $(P<0.05)$ than those of control. Significant differences $(P<0.05)$ were
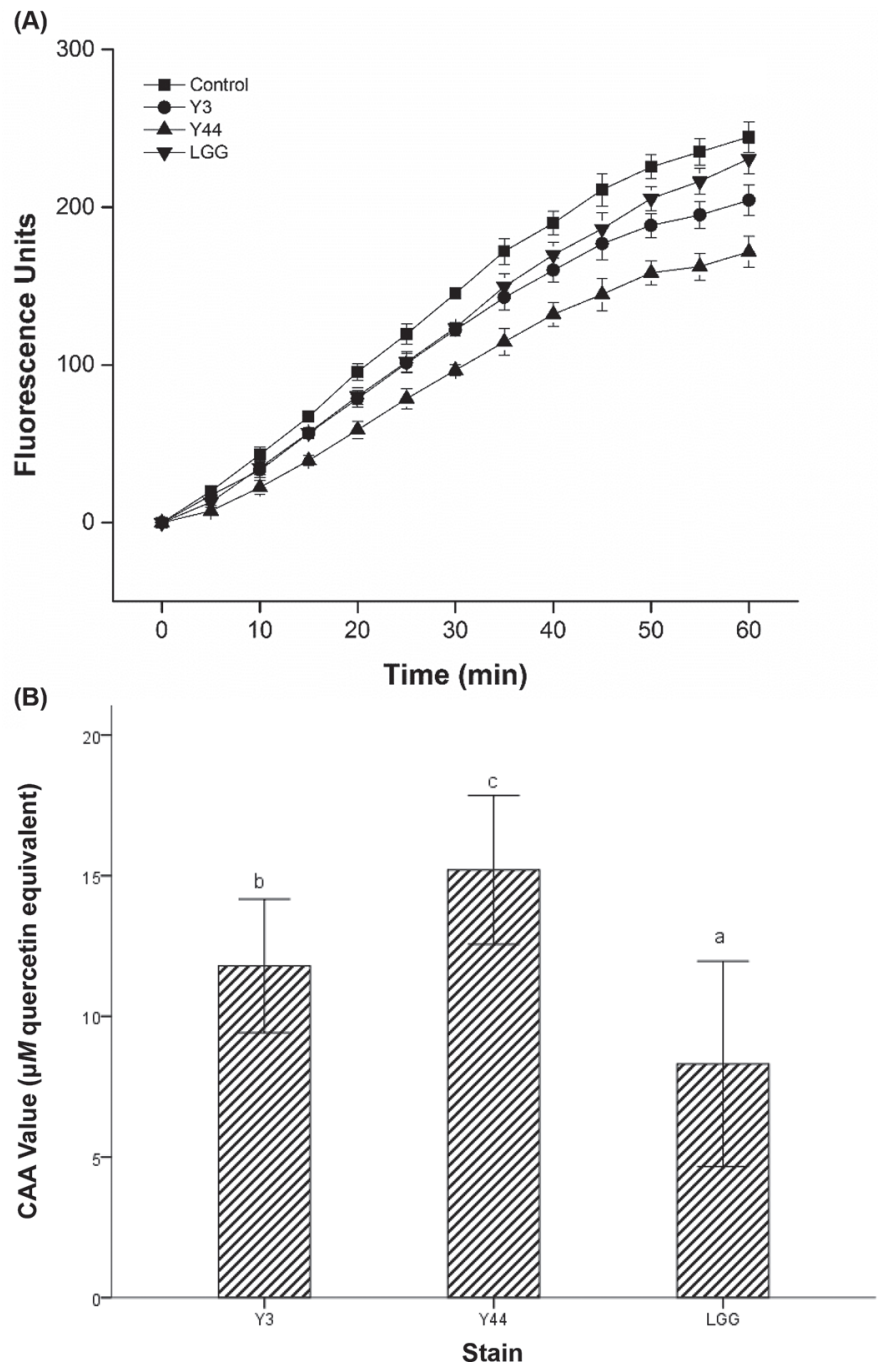

Figure 6. Peroxyl radical-induced oxidation of $2^{\prime}, 7^{\prime}$-dichlorofluorescin (DCFH) to oxidized DCFH in HT-29 cells and the inhibition of oxidation by the 3 lactobacilli strains over time (A). Cellular antioxidant activity (CAA) assay values of 3 lactobacilli strains in HT-29 cells $(B)$. The results are expressed as mean \pm SD $(n=6)$. Different lowercase letters $(\mathrm{a}-\mathrm{c})$ on columns indicate a significant difference at the 0.05 level. observed in CAA values between 3 lactobacilli strains L. casei Y3, L. plantarum Y44, and LGG with 11.10 , 15.76, and $8.61 \mu M$ quercetin equivalents, respectively, as shown in Figure 6B. Lactobacillus plantarum Y44 exerted the significantly highest CAA value among the 3 lactobacilli strains $(P<0.05)$.

Xing et al. (2015b) reported that RAW264.7, Caco-2, and EA.hy926 cell lines could be used as cell models to assay the cellular antioxidant activity of lactobacilli strains. In this study quercetin and 3 lactobacilli strains significantly inhibited the production of intracellular ROS without creating obvious cytotoxic effects in HT29 cells, indicating that HT-29 cell lines could be a cell model to assay the cellular antioxidant activity of lactobacilli strains.

\section{Protection of Lactobacilli Strains for HT-29 Cells Against $\mathrm{H}_{2} \mathrm{O}_{2}$ Injury}

Cell Viability Assay and Western Blot Assay. The HT-29 cells were extremely sensitive to $\mathrm{H}_{2} \mathrm{O}_{2}$, exhibiting 50\% survival rate at $150 \mu M \mathrm{H}_{2} \mathrm{O}_{2}$ (Figure 7). However, when the HT-29 cells were pretreated with lactobacilli strains $\mathrm{Y} 3$ and $\mathrm{Y} 44$ for $2 \mathrm{~h}$ before being exposed to $\mathrm{H}_{2} \mathrm{O}_{2}$, HT-29 cell viability increased significantly $(P<0.05)$ compared with that of $\mathrm{H}_{2} \mathrm{O}_{2}$ group. The viability of HT-29 cells pretreated by L. plantarum Y44 was significantly higher compared with other test groups $(P<0.05)$.

To further assess how L. plantarum Y44 increased cell viability of HT-29 cells injured by $\mathrm{H}_{2} \mathrm{O}_{2}$, the ex-

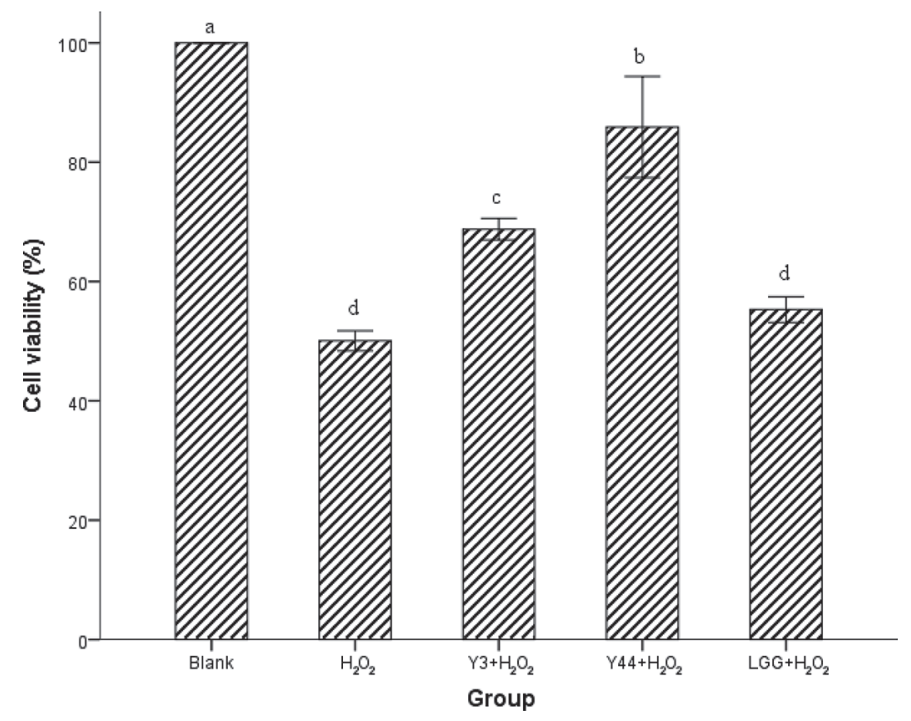

Figure 7. Protective effects of lactobacilli strains on cell viabilities of HT-29 injured by $\mathrm{H}_{2} \mathrm{O}_{2}$. The results are expressed as mean $\pm \mathrm{SD}$ (n $=6)$. Different lowercase letters $(\mathrm{a}-\mathrm{d})$ on columns indicate a significant difference at the 0.05 level. 
pression of Bcl-2, Bax, and Hsp70 were evaluated by Western blotting analysis. It is well known that Bax and Bcl-2 have been shown to play an important role in the regulation of mitochondria-mediated cell apoptosis (Huang et al., 2015; Yin et al., 2017). As shown in Figure $8 \mathrm{~B}$ and $8 \mathrm{D}$, the Bax expression of the HT-29 cells injured by $\mathrm{H}_{2} \mathrm{O}_{2}$ alone was upgrading about 1.24 -fold $(P<0.05)$, Bcl-2 expression was downgrading about 0.7 -fold $(P<0.05)$, indicating that $\mathrm{H}_{2} \mathrm{O}_{2}$ induced HT29 cell apoptosis. After treatment by L. plantarum Y44, the expression of Bcl-2 in HT-29 cells increased significantly $(P<0.05)$, and the expression of Bax decreased. Taken together, L. plantarum Y44 induced a dramatic decrease in the Bax/Bcl-2 ratio compared with $\mathrm{H}_{2} \mathrm{O}_{2}$ group $(P<0.05)$ as shown in Figure $8 \mathrm{E}$, indicating that the apoptosis induced by $\mathrm{H}_{2} \mathrm{O}_{2}$ was relieved. This result was in accordance with a previous study that showed L. acidophilus MTCC 447 could upgrade Bcl-2/ BAX relative expression to restrain acetaminophen oxidation-induced cell apoptosis of hepatocytes (Sharma et al., 2011).

Heat shock proteins, a group of evolutionary conserved proteins, would be synthesized rapidly by most cells responding to stress-related events, such as oxidative stress, of which Hsp70 was significantly synthesized (Nemeth et al., 2006). In this study, $\mathrm{H}_{2} \mathrm{O}_{2}$ induced HT-29 cells to overexpress Hsp70 significantly about 1.19-fold $(P<0.05)$ compared with that of the control group (Figure 9B), indicating that $\mathrm{H}_{2} \mathrm{O}_{2}$ caused oxidative stress to HT-29 cells. However, pretreatment with
(A)

\section{Control $\quad \mathrm{H}_{2} \mathrm{O}_{2} \quad \mathrm{H}_{2} \mathrm{O}_{2}+\mathrm{Y} 44$}

Bax

$\beta$-Actin

(B)

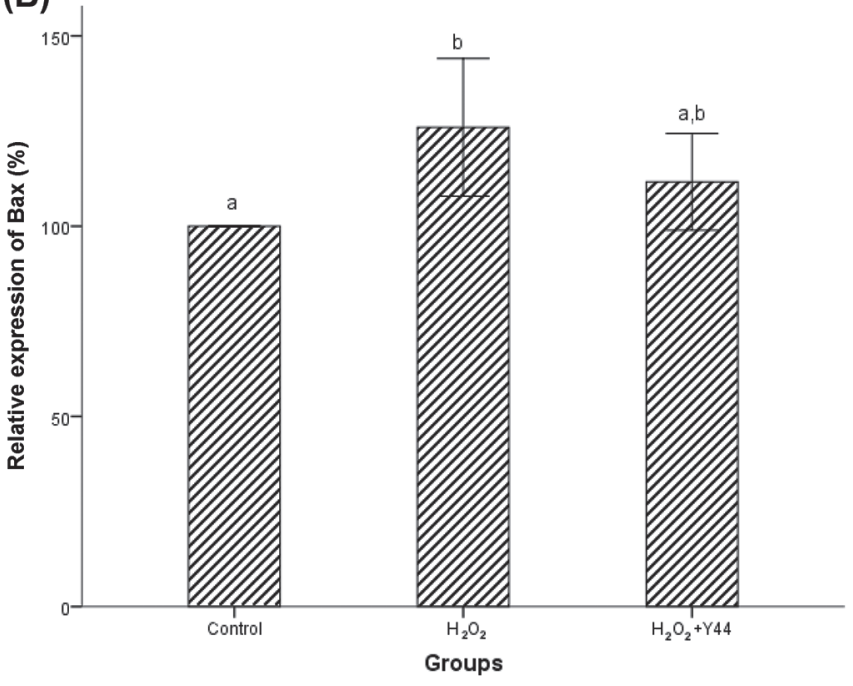

(C) Control $\quad \mathrm{H}_{2} \mathrm{O}_{2}$ $\mathrm{H}_{2} \mathrm{O}_{2}+\mathrm{Y} 44$

$\mathrm{Bcl}-2$

$\beta$-Actin
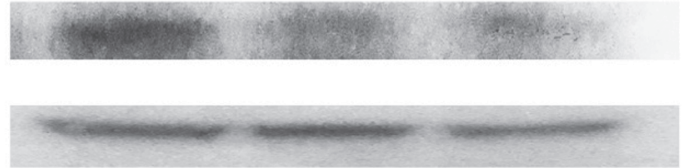

(D)

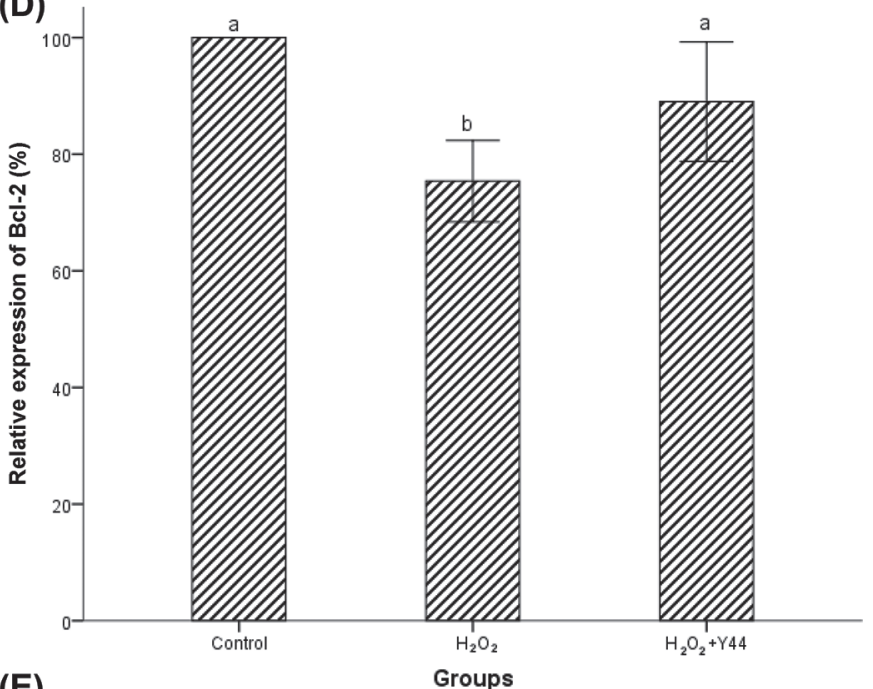

(E)

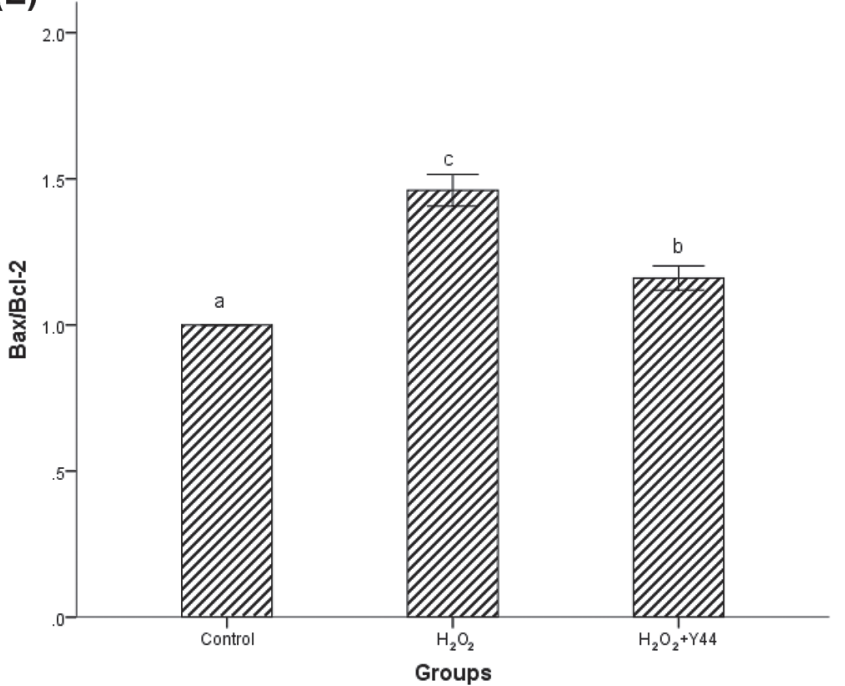

Figure 8. Protective effects of Lactobacillus plantarum Y44 on expression of Bcl-2-associated X protein (Bax; A, B), B-cell lymphoma 2 (Bcl-2; C, D), and Bax/Bcl-2 (E) in HT-29 cells with $\mathrm{H}_{2} \mathrm{O}_{2}$-induced oxidative stress. The results are expressed as mean $\pm \mathrm{SD}$ ( $\mathrm{n}=6$ ). Different lowercase letters $(\mathrm{a}-\mathrm{c})$ on columns indicate a significant difference at the 0.05 level. 
(A)

\section{Control $\quad \mathrm{H}_{2} \mathrm{O}_{2} \quad \mathrm{H}_{2} \mathrm{O}_{2}+\mathrm{Y} 44$}
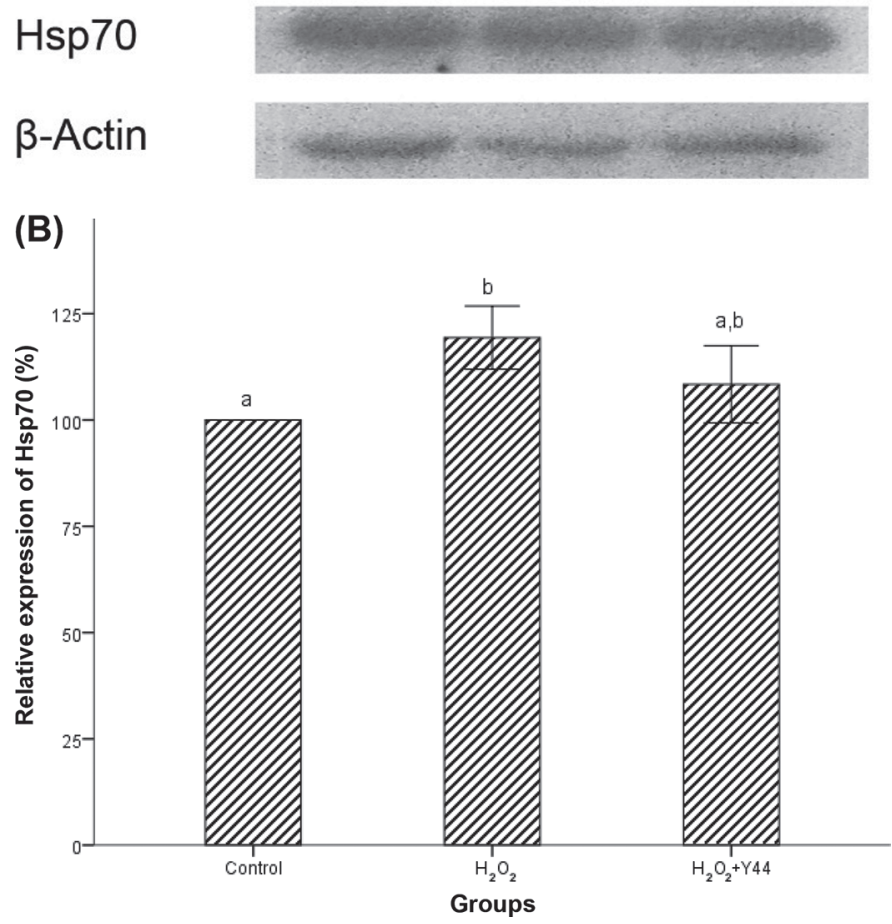

Figure 9. Protective effects of Lactobacillus plantarum Y44 on expression of heat shock protein (Hsp) 70 in HT-29 cells with $\mathrm{H}_{2} \mathrm{O}_{2}$ induced oxidative stress. The results are expressed as mean \pm SD (n $=6)$. Different lowercase letters $(\mathrm{a}, \mathrm{b})$ on columns indicate a significant difference at the 0.05 level.

L. plantarum Y44 decreased Hsp70 expression of the HT-29 cells, indicating that L. plantarum Y44 relieved the oxidative stress.

SOD, GPx, and MDA Assays. Malondialdehyde, an end product of lipid peroxidation, is often used as an indicator of oxidative damage, which could ultimately lead to disruption of cellular metabolism (Liao et al., 2014). In this study, the high MDA level of $\mathrm{H}_{2} \mathrm{O}_{2}$ group indicated that lipid peroxidation of HT-29 cells was accelerated (Table 2). The treatment of the 3 lactobacilli strains significantly decreased the MDA level of the HT-29 cells compared with that of the HT-29 cells only treated by $\mathrm{H}_{2} \mathrm{O}_{2}(P<0.05)$.

A good antioxidant is not only a good radical scavenger, but also regulates the intracellular antioxidant enzymes during cellular metabolism (Jones, 2006). Through a series of enzymatic reactions, intracellular antioxidant enzymes convert reactive radicals into less active radicals, of which SOD and GPx are key enzymes in the defense against the adverse effects of ROS (Wen et al., 2016). In this study, $\mathrm{H}_{2} \mathrm{O}_{2}$ treatment decreased SOD and GPx activities of HT-29 cells compared with the control group $(P<0.05)$, whereas pretreatment with lactobacilli strains could restore SOD and GPx activities of $\mathrm{H}_{2} \mathrm{O}_{2}$-injured HT-29 cells, as shown in Table 3. Lactobacillus plantarum Y44 significantly increased SOD and GPx activities of HT-29 cells compared with other 2 lactobacilli strains $(P<0.05)$. Analogously, Xing et al. (2015a) found that L. casei CCFM-JU 9 and L. rhamnosus CCFM-JU 237 could restore antioxidant enzymes activities and decrease MDA level of the HepG2 cells injured by $\mathrm{H}_{2} \mathrm{O}_{2}$. Lactobacillus mucosae LMU1001 was also confirmed to significantly upregulate gene expression of antioxidant genes in HT-29 cells and Caco-2 cells (Yu et al., 2016).

According to the results of the antioxidant assays of the cellular model, L. plantarum Y44 could inhibit the production of intracellular ROS without creating obvious cytotoxic effects, and could significantly restore SOD and GPx activities and decrease MDA level $(P<$ 0.05) of HT-29 cells, indicating that L. plantarum Y44 was effective in protecting HT-29 cells against oxidative stress.

Correlations of the Results of Different Antioxidant Activity Assays. In this study, we compared the correlation of the results of different antioxidant activity assays, as shown in Table 3. The DPPH free radical scavenging activities of the strains had no significant correlation with other antioxidant activities $(P$ $>0.05)$. In comparison of the results of the different chemical methods, the strains' antioxidant activities

Table 2. Effects of lactobacilli strains on superoxide dismutase (SOD), glutathione peroxidase (GPx) activity, and malondialdehyde (MDA) level of HT-29 cells treated by $\mathrm{H}_{2} \mathrm{O}_{2}{ }^{1}$

\begin{tabular}{|c|c|c|c|}
\hline Group & $\begin{array}{c}\text { SOD } \\
\left(\mathrm{U} \cdot \mathrm{mg}^{-1}\right. \\
\text { of protein })\end{array}$ & $\begin{array}{c}\text { GPx } \\
\left(\mathrm{U} \cdot \mathrm{mg}^{-1}\right. \\
\text { of protein) }\end{array}$ & $\begin{array}{c}\text { MDA } \\
\left(\mathrm{n} M \cdot \mathrm{mg}^{-1}\right. \\
\text { of protein) }\end{array}$ \\
\hline Blank & $16.35 \pm 0.37^{\mathrm{d}}$ & $25.90 \pm 2.73^{\mathrm{c}}$ & $0.56 \pm 0.20^{\mathrm{a}}$ \\
\hline $\mathrm{H}_{2} \mathrm{O}_{2}$ model & $2.41 \pm 0.07^{\mathrm{a}}$ & $11.38 \pm 0.35^{\mathrm{a}}$ & $3.43 \pm 0.43^{\mathrm{e}}$ \\
\hline $\mathrm{H}_{2} \mathrm{O}_{2}+$ Lactobacillus casei $\mathrm{Y} 3$ & $4.46 \pm 0.18^{\mathrm{b}}$ & $13.03 \pm 0.79^{\mathrm{a}}$ & $1.50 \pm 0.36^{\mathrm{c}}$ \\
\hline $\mathrm{H}_{2} \mathrm{O}_{2}+$ Lactobacillus plantarum $\mathrm{Y} 44$ & $7.24 \pm 0.3^{\mathrm{c}}$ & $17.93 \pm 1.57^{\mathrm{b}}$ & $1.19 \pm 0.19^{\mathrm{bc}}$ \\
\hline $\mathrm{H}_{2} \mathrm{O}_{2}+$ Lactobacillus rhamnosus $\mathrm{GG}$ & $2.57 \pm 0.19^{\mathrm{a}}$ & $11.68 \pm 1.01^{\mathrm{a}}$ & $2.91 \pm 0.46^{\mathrm{d}}$ \\
\hline
\end{tabular}

${ }^{a-e}$ Different superscripts within a column indicate a significant difference at the 0.05 level.

${ }^{1}$ The results are expressed as mean $\pm \mathrm{SD}(\mathrm{n}=3)$. 
Table 3. Correlation coefficient matrix between different antioxidant assays in lactobacilli strains ${ }^{1}$

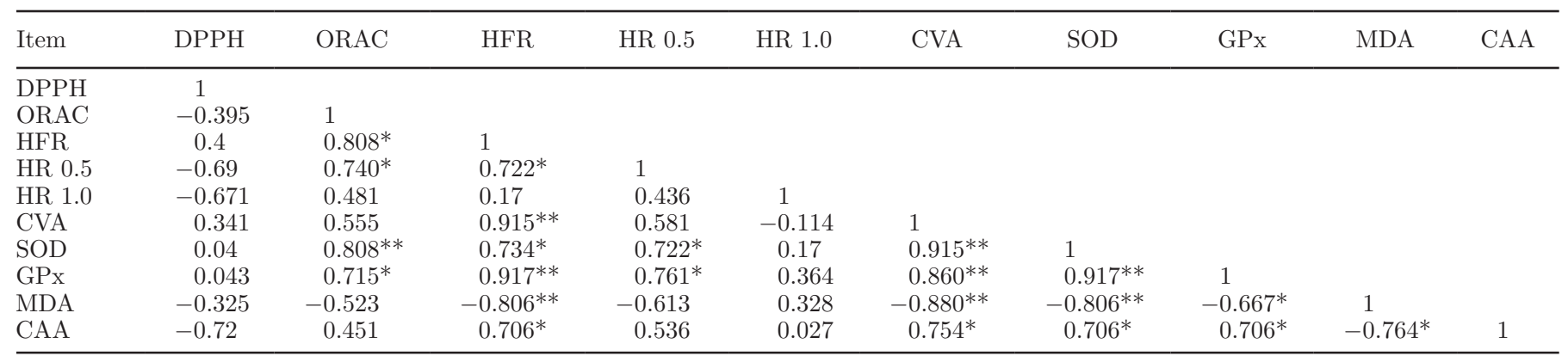

${ }^{1} \mathrm{DPPH}=1,1$-diphenyl-2-picrylhydrazyl free radical scavenging activity; HR 0.5/1.0 = hydrogen peroxide resistance in $0.5 / 1.0 \mathrm{~m} M$; ORAC = oxygen radical absorbance capacity; HFR = hydroxyl free radical scavenging activity; CVA = cell viability assay; SOD = superoxide dismutase; $\mathrm{GPx}=$ glutathione peroxidase; MDA = malondialdehyde; CAA = cellular antioxidant activity assay.

${ }^{*}$ Correlation is significant at the 0.05 level (2-tailed); ${ }^{*}$ correlation is significant at the 0.01 level (2-tailed).

of the ORAC assay, resistance to $0.5 \mathrm{mM} \mathrm{H} \mathrm{H}_{2} \mathrm{O}_{2}$, and hydroxyl radical scavenging assay had a significant correlation with each other $(P<0.05)$. The result was similar to the reports of Huang et al. (2014), in which DPPH free radical scavenging activity had no significant correlation with ORAC value.

In this study, the cell viability of HT-29 injured by $\mathrm{H}_{2} \mathrm{O}_{2}$ and the CAA assay results showed a significant correlation with hydroxyl radical scavenging activity $(P$ $<0.05$ ). Moreover, SOD and GPx activities of HT-29 cells injured by $\mathrm{H}_{2} \mathrm{O}_{2}$ showed a significant correlation with the results of the ORAC assay, resistance to 0.5 $\mathrm{m} M \mathrm{H}_{2} \mathrm{O}_{2}$, and hydroxyl radical scavenging activity. We speculated that L. plantarum Y44 protect HT-29 cells against oxygen free radical injury through scavenging ROS, such as APAP and $\mathrm{H}_{2} \mathrm{O}_{2}$. The hydroxyl radical scavenging activities of lactobacilli strains to some extent reflect the protective effect of lactobacilli strains on HT-29 cells. The hydroxyl radical scavenging activity assay may be an effective chemical antioxidant method to verify antioxidant activity of lactobacilli strains.

In the protection of lactobacilli strains for HT-29 cells against $\mathrm{H}_{2} \mathrm{O}_{2}$ injury, the cell viability, SOD and GPx activities, and MDA level of HT-29 cells were found to have a significant correlation with each other $(P<$ $0.05)$, indicating that the lactobacilli strains improved the viability of HT-29 cells by restoring antioxidant enzyme activities. The results of the CAA assay were significantly correlated with 4 indexes of the protection of lactobacilli strains for $\mathrm{H}_{2} \mathrm{O}_{2}$-injured HT-29 cells $(P<$ 0.05), indicating that L. plantarum Y44 protects HT-29 cells against ABAP injury through activating intracellular antioxidant enzymes.

Correlation analysis of the results of different antioxidant activity assays showed that the antioxidant activity analysis of lactobacilli strains should be carried out using more than one chemical method as well as the cellular model.

\section{CONCLUSIONS}

In summary, the present study showed that L. plantarum Y44 could scavenge oxygen free radicals, such as DPPH radicals, hydroxyl free radicals, and oxygen free radicals. Furthermore, L. plantarum Y44 significantly inhibited the production of intracellular ROS in HT29 cells, increased survival rate of $\mathrm{H}_{2} \mathrm{O}_{2}$-injured HT-29 cells, activated SOD and GPx activities, and decreased MDA level of the HT-29 cells. It was speculated that L. plantarum Y44 protected HT-29 cells against oxidative injury through scavenging ROS and activating intracellular antioxidant enzymes. And L. plantarum Y44 had the probiotic potential to exert antioxidant activity. According to the correlation analysis between several chemical antioxidant methods and antioxidant cellular models, combining hydroxyl free radical scavenging assay, ORAC assay, and protection for HT-29 cells against $\mathrm{H}_{2} \mathrm{O}_{2}$ injury assay could be an effective procedure to screen lactobacilli strains with antioxidant activity.

\section{ACKNOWLEDGMENTS}

This research project was supported by the National Natural Science Foundation of China, Beijing (no. 31571813, no. 31671828).

\section{REFERENCES}

Amaretti, A., M. Di Nunzio, A. Pompei, S. Raimondi, M. Rossi, and A. Bordoni. 2013. Antioxidant properties of potentially probiotic bacteria: In vitro and in vivo activities. Appl. Microbiol. Biotechnol. 97:809-817. https://doi.org/10.1007/s00253-012-4241-7.

Arasu, M. V., D. H. Kim, P. I. Kim, M. W. Jung, S. Ilavenil, M. Jane, K. D. Lee, N. A. Al-Dhabi, and K. C. Choi. 2014. In vitro antifungal, probiotic and antioxidant properties of novel Lactobacillus plantarum K46 isolated from fermented sesame leaf. Ann. Microbiol. 64:1333-1346. https://doi.org/10.1007/s13213-013-0777-8.

Bao, Y., Y. Zhang, H. Li, Y. Liu, S. Wang, X. Dong, F. Su, G. Yao, T. Sun, and H. Zhang. 2012. In vitro screen of Lactobacillus plan- 
tarum as probiotic bacteria and their fermented characteristics in soymilk. Ann. Microbiol. 62:1311-1320. https://doi.org/10.1007/ s13213-011-0377-4.

Bao, Y., Y. Zhang, Y. Zhang, Y. Liu, S. Wang, X. Dong, Y. Wang, and H. Zhang. 2010. Screening of potential probiotic properties of Lactobacillus fermentum isolated from traditional dairy products. Food Control 21:695-701. https://doi.org/10.1016/j.foodcont.2009 .10.010.

Cappa, F., D. Cattivelli, and P. S. Cocconcelli. 2005. The uvrA gene is involved in oxidative and acid stress responses in Lactobacillus helveticus CNBL1156. Res. Microbiol. 156:1039-1047. https://doi .org/10.1016/j.resmic.2005.06.003.

Chen, P., Q. Zhang, H. Dang, X. Liu, F. Tian, J. Zhao, Y. Chen, H. Zhang, and W. Chen. 2014. Screening for potential new probiotic based on probiotic properties and $\alpha$-glucosidase inhibitory activity. Food Control 35:65-72. https://doi.org/10.1016/j.foodcont .2013.06.027.

Das, D., and A. Goyal. 2015. Antioxidant activity and $\gamma$-aminobutyric acid (GABA) producing ability of probiotic Lactobacillus plantarum DM5 isolated from Marcha of Sikkim. Lebensm. Wiss. Technol. 61:263-268. https://doi.org/10.1016/j.lwt.2014.11.013.

Elfahri, K. R., T. Vasiljevic, T. Yeager, and O. N. Donkor. 2016. Anticolon cancer and antioxidant activities of bovine skim milk fermented by selected Lactobacillus helveticus strains. J. Dairy Sci. 99:31-40. https://doi.org/10.3168/jds.2015-10160.

González-Manzano, S., A. M. González-Paramás, L. Delgado, S. Patianna, F. Surco-Laos, M. Dueñas, and C. Santos-Buelga. 2012. Oxidative status of stressed Caenorhabditis elegans treated with epicatechin. J. Agric. Food Chem. 60:8911-8916. https://doi.org/ $10.1021 /$ jf3004256.

Guarner, F., and J. R. Malagelada. 2003. Gut flora in health and disease. Lancet 361:512-519. https://doi.org/10.1016/S0140 $-6736(03) 12489-0$.

Huang, G., J. Mao, Z. Ji, and A. Ailati. 2015. Stachyose-induced apoptosis of Caco-2 cells via the caspase-dependent mitochondrial pathway. Food Funct. 6:765-771. https://doi.org/10.1039/c4fo01017e.

Huang, H., Y. Sun, S. Lou, H. Li, and X. Ye. 2014. In vitro digestion combined with cellular assay to determine the antioxidant activity in Chinese bayberry (Myrica rubra Sieb. et Zucc.) fruits: A comparison with traditional methods. Food Chem. 146:363-370. https: //doi.org/10.1016/j.foodchem.2013.09.071.

Ianniello, R. G., A. Ricciardi, E. Parente, A. Tramutola, A. Reale, and T. Zotta. 2015. Aeration and supplementation with heme and menaquinone affect survival to stresses and antioxidant capability of Lactobacillus casei strains. Lebensm. Wiss. Technol. 60:817-824. https://doi.org/10.1016/j.lwt.2014.10.020.

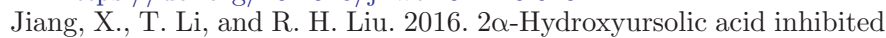
cell proliferation and induced apoptosis in MDA-MB-231 human breast cancer cells through the p38/MAPK signal transduction pathway. J. Agric. Food Chem. 64:1806-1816. https://doi.org/10 .1021/acs.jafc.5b04852.

Jones, D. P. 2006. Redefining oxidative stress. Antioxid. Redox Signal. 8:1865-1879. https://doi.org/10.1089/ars.2006.8.1865.

Kanno, T., T. Kuda, C. An, H. Takahashi, and B. Kimura. 2012. Radical scavenging capacities of saba-narezushi, Japanese fermented chub mackerel, and its lactic acid bacteria. Lebensm. Wiss. Technol. 47:25-30. https://doi.org/10.1016/j.lwt.2012.01.007.

Kao, T. H., and B. H. Chen. 2006. Functional components in soybean cake and their effects on antioxidant activity. J. Agric. Food Chem. 54:7544-7555. https://doi.org/10.1021/jf061586x.

Kono, Y., and I. Fridovich. 1983. Isolation and characterization of the pseudocatalase of Lactobacillus plantarum. J. Biol. Chem. 258:6015-6019.

Kuda, T., M. Kawahara, M. Nemoto, H. Takahashi, and B. Kimura. 2014. In vitro antioxidant and anti-inflammation properties of lactic acid bacteria isolated from fish intestines and fermented fish from the Sanriku Satoumi region in Japan. Food Res. Int. 64(Supplement C):248-255. https://doi.org/10.1016/j.foodres .2014.06.028.

Kullisaar, T., M. Zilmer, M. Mikelsaar, T. Vihalemm, H. Annuk, C. Kairane, and A. Kilk. 2002. Two antioxidative lactobacilli strains as promising probiotics. Int. J. Food Microbiol. 72:215-224. https: //doi.org/10.1016/S0168-1605(01)00674-2.

Li, C., Q. Huang, X. Fu, X. J. Yue, R. H. Liu, and L. J. You. 2015. Characterization, antioxidant and immunomodulatory activities of polysaccharides from Prunella vulgaris Linn. Int. J. Biol. Macromol. 75:298-305. https://doi.org/10.1016/j.ijbiomac.2015.01.010.

Li, C., X. Li, L. You, X. Fu, and R. H. Liu. 2017. Fractionation, preliminary structural characterization and bioactivities of polysaccharides from Sargassum pallidum. Carbohydr. Polym. 155:261270. https://doi.org/10.1016/j.carbpol.2016.08.075.

Li, J. Y., M. M. Jin, J. Meng, S. M. Gao, and R. R. Lu. 2013. Exopolysaccharide from Lactobacillus planterum LP6: Antioxidation and the effect on oxidative stress. Carbohydr. Polym. 98:1147-1152. https://doi.org/10.1016/j.carbpol.2013.07.027.

Li, S., Y. Zhao, L. Zhang, X. Zhang, L. Huang, D. Li, C. Niu, Z. Yang, and Q. Wang. 2012. Antioxidant activity of Lactobacillus plantarum strains isolated from traditional Chinese fermented foods. Food Chem. 135:1914-1919. https://doi.org/10.1016/j.foodchem 2012.06.048.

Liao, W., Z. Ning, L. Chen, Q. Wei, E. Yuan, J. Yang, and J. Ren. 2014. Intracellular antioxidant detoxifying effects of diosmetin on 2, 2-azobis (2-amidinopropane) dihydrochloride (AAPH)-induced oxidative stress through inhibition of reactive oxygen species generation. J. Agric. Food Chem. 62:8648-8654. https://doi.org/10 $.1021 / \mathrm{jf502359x}$.

Lin, M. Y., and F. J. Chang. 2000. Antioxidative effect of intestinal bacteria Bifidobacterium longum ATCC 15708 and Lactobacillus acidophilus ATCC 4356. Dig. Dis. Sci. 45:1617-1622. https://doi .org/10.1023/A:1005577330695.

López-Alarcón, C., and A. Denicola. 2013. Evaluating the antioxidant capacity of natural products: A review on chemical and cellularbased assays. Anal. Chim. Acta 763:1-10. https://doi.org/10 .1016/j.aca.2012.11.051.

Mishra, V., C. Shah, N. Mokashe, R. Chavan, H. Yadav, and J. Prajapati. 2015. Probiotics as potential antioxidants: A systematic review. J. Agric. Food Chem. 63:3615-3626. https://doi.org/10 $.1021 /$ jf506326t

Nemeth, E., S. Fajdiga, J. Malago, J. Koninkx, P. Tooten, and J. Van Dijk. 2006. Inhibition of Salmonella-induced IL-8 synthesis and expression of Hsp70 in enterocyte-like Caco-2 cells after exposure to non-starter lactobacilli. Int. J. Food Microbiol. 112:266-274. https://doi.org/10.1016/j.ijfoodmicro.2006.09.002.

Niki, E. 2010. Assessment of antioxidant capacity in vitro and in vivo. Free Radic. Biol. Med. 49:503-515. https://doi.org/10.1016/j freeradbiomed.2010.04.016.

Ren, D., C. Li, Y. Qin, R. Yin, S. Du, F. Ye, C. Liu, H. Liu, M. Wang, Y. Li, Y. Sun, X. Li, M. Tian, and N. Jin. 2014. In vitro evaluation of the probiotic and functional potential of Lactobacillus strains isolated from fermented food and human intestine. Anaerobe 30:110. https://doi.org/10.1016/j.anaerobe.2014.07.004.

Saide, J. A. O., and S. E. Gilliland. 2005. Antioxidative activity of lactobacilli measured by oxygen radical absorbance capacity. J. Dairy Sci. 88:1352-1357. https://doi.org/10.3168/jds.S0022 -0302(05)72801-0.

Schaich, K. M., X. Tian, and J. Xie. 2015. Hurdles and pitfalls in measuring antioxidant efficacy: A critical evaluation of ABTS, DPPH, and ORAC assays. J. Funct. Foods 14:111-125. https://doi.org/10 .1016/j.jff.2015.01.043.

Serrano, L. M., D. Molenaar, M. Wels, B. Teusink, P. A. Bron, W. M. De Vos, and E. J. Smid. 2007. Thioredoxin reductase is a key factor in the oxidative stress response of Lactobacillus plantarum WCFS1. Microb. Cell Fact. 6:29. https://doi.org/10.1186/1475 $-2859-6-29$.

Sharma, S., R. L. Singh, and P. Kakkar. 2011. Modulation of Bax/Bcl2 and caspases by probiotics during acetaminophen induced apoptosis in primary hepatocytes. Food Chem. Toxicol. 49:770-779. https://doi.org/10.1016/j.fct.2010.11.041.

Song, W., C. M. Derito, M. K. Liu, X. He, M. Dong, and R. H. Liu. 2010. Cellular antioxidant activity of common vegetables. J. Agric. Food Chem. 58:6621-6629. https://doi.org/10.1021/jf9035832. 
Tang, W., Z. Xing, W. Hu, C. Li, J. Wang, and Y. Wang. 2016. Antioxidative effects in vivo and colonization of Lactobacillus plantarum MA2 in the murine intestinal tract. Appl. Microbiol. Biotechnol. 100:7193-7202. https://doi.org/10.1007/s00253-016-7581-x.

Tang, W., Z. Xing, C. Li, J. Wang, and Y. Wang. 2017. Molecular mechanisms and in vitro antioxidant effects of Lactobacillus plantarum MA2. Food Chem. 221:1642-1649. https://doi.org/10.1016/ j.foodchem.2016.10.124.

Vijayakumar, M., S. Ilavenil, D. H. Kim, M. V. Arasu, K. Priya, and K. C. Choi. 2015. In vitro assessment of the probiotic potential of Lactobacillus plantarum KCC-24 isolated from Italian rye-grass (Lolium multiflorum) forage. Anaerobe 32:90-97. https://doi.org/ 10.1016/j.anaerobe.2015.01.003.

Wang, Y., Y. Li, J. Xie, Y. Zhang, J. Wang, X. Sun, and H. Zhang. 2013. Protective effects of probiotic Lactobacillus casei Zhang against endotoxin-and D-galactosamine-induced liver injury in rats via anti-oxidative and anti-inflammatory capacities. Int. Immunopharmacol. 15:30-37. https://doi.org/10.1016/j.intimp.2012.10 .026 .

Wang, Y., Y. Wu, Y. Wang, H. Xu, X. Mei, D. Yu, Y. Wang, and W. Li. 2017. Antioxidant properties of probiotic bacteria. Nutrients 9:521. https://doi.org/10.3390/nu9050521

Wen, L., G. Zheng, L. You, A. M. Abbasi, T. Li, X. Fu, and R. H. Liu. 2016. Phytochemical profiles and cellular antioxidant activity of Malus doumeri (bois) chevalier on 2,2'-azobis (2-amidinopropane) dihydrochloride (ABAP)-induced oxidative stress. J. Funct. Foods 25:242-256. https://doi.org/10.1016/j.jff.2016.06.004.

Wolfe, K. L., and R. H. Liu. 2007. Cellular antioxidant activity (CAA) assay for assessing antioxidants, foods, and dietary supplements. J. Agric. Food Chem. 55:8896-8907. https://doi.org/10.1021/ jf0715166.

Wolfe, K. L., and R. H. Liu. 2008. Structure-activity relationships of flavonoids in the cellular antioxidant activity assay. J. Agric. Food Chem. 56:8404-8411. https://doi.org/10.1021/jf8013074.

Xiao, Y., L. Wang, X. Rui, W. Li, X. Chen, M. Jiang, and M. Dong. 2015. Enhancement of the antioxidant capacity of soy whey by fermentation with Lactobacillus plantarum B1-6. J. Funct. Foods 12:33-44. https://doi.org/10.1016/j.jff.2014.10.033.

Xing, J., G. Wang, Z. Gu, X. Liu, Q. Zhang, J. Zhao, H. Zhang, Y. Chen, and W. Chen. 2015a. Cellular model to assess the antioxi- dant activity of lactobacilli. RSC Advances 5:37626-37634. https: //doi.org/10.1039/C5RA02215K.

Xing, J., G. Wang, Q. Zhang, X. Liu, Z. Gu, H. Zhang, Y. Chen, and W. Chen. 2015c. Determining antioxidant activities of lactobacilli cell-free supernatants by cellular antioxidant assay: A comparison with traditional methods. PLoS One 10:e0119058. https://doi.org/ 10.1371/journal.pone.0119058.

Xing, J., G. Wang, Q. Zhang, X. Liu, B. Yin, D. Fang, and W. Chen. 2015b. Determining antioxidant activities of lactobacilli by cellular antioxidant assay in mammal cells. J. Funct. Foods 19:554-562. https://doi.org/10.1016/j.jff.2015.09.017.

Yin, P., J. Zhang, L. Yan, L. Yang, L. Sun, L. Shi, C. Ma, and Y. Liu. 2017. Urolithin C, a gut metabolite of ellagic acid, induces apoptosis in PC12 cells through a mitochondria-mediated pathway. RSC Advances 7:17254-17263. https://doi.org/10.1039/C7RA01548H.

Yu, X., S. Li, D. Yang, L. Qiu, Y. Wu, D. Wang, N. Shah, F. Xu, and H. Wei. 2016. A novel strain of Lactobacillus mucosae isolated from a Gaotian villager improves in vitro and in vivo antioxidant as well as biological properties in D-galactose-induced aging mice. J. Dairy Sci. 99:903-914. https://doi.org/10.3168/jds.2015-10265.

Zhang, L., C. Liu, D. Li, Y. Zhao, X. Zhang, X. Zeng, Z. Yang, and S. Li. 2013. Antioxidant activity of an exopolysaccharide isolated from Lactobacillus plantarum C88. Int. J. Biol. Macromol. 54:270 275. https://doi.org/10.1016/j.ijbiomac.2012.12.037.

Zhang, Y., R. Du, L. Wang, and H. Zhang. 2010. The antioxidative effects of probiotic Lactobacillus casei Zhang on the hyperlipidemic rats. Eur. Food Res. Technol. 231:151-158. https://doi.org/ 10.1016/j.ijbiomac.2012.12.037.

Zhao, J., F. Tian, S. Yan, Q. Zhai, H. Zhang, and W. Chen. 2018 Lactobacillus plantarum CCFM10 alleviating oxidative stress and restoring the gut microbiota in D-galactose-induced aging mice. Food Funct. https://doi.org/10.1039/c7fo01574g.

Zhu, R., M. T. Mok, W. Kang, S. S. Lau, W. K. Yip, Y. Chen, P. B. Lai, V. W. Wong, K. To, J. J. Sung, A. S. Cheng, and H. L. Chan. 2015. Truncated HBx-dependent silencing of GAS2 promotes hepatocarcinogenesis through deregulation of cell cycle, senescence and p53-mediated apoptosis. J. Pathol. 237:38-49. https://doi .org/10.1002/path.4554 